Article

\title{
Appropriate Ammonium-Nitrate Ratio Improves Nutrient Accumulation and Fruit Quality in Pepper (Capsicum annuum L.)
}

\author{
Jing Zhang ${ }^{1}$, Jian Lv ${ }^{1}$, Mohammed Mujitaba Dawuda ${ }^{1,2}$, Jianming Xie ${ }^{1, *}$, Jihua $\mathrm{Yu}^{1}{ }^{1}$, Jing Li ${ }^{1}$, \\ Xiaodan Zhang ${ }^{1}$, Chaonan Tang ${ }^{1}$, Cheng Wang ${ }^{1}$ and Yantai Gan ${ }^{3}$ \\ 1 College of Horticulture, Gansu Agricultural University, Yingmen Village, Anning District, Lanzhou 730070, \\ China; Jingzhanggs2019@outlook.com (J.Z.); lvjian@gsau.edu.cn (J.L.); mmdawuda@yahoo.com (M.M.D.); \\ yujihua@gsau.edu.cn (J.Y.); lj@gsau.edu.cn (J.L.); zhangxiaodan1993@outlook.com (X.Z.); \\ Tangchaonan1041@outlook.com (C.T.); GSAUPHD0810@outlook.com (C.W.) \\ 2 Department of Horticulture, Faculty of Agriculture, University for Development Studies, \\ Tamale P.O. Box TL 1882, Ghana \\ 3 Agriculture and Agri-Food Canada, Swift Current Research and Development Centre, Swift Current, \\ SK S9H 3X2, Canada; yantai.gan@canada.ca \\ * Correspondence: xiejianming@gsau.edu.cn; Tel.: +86-138-933-357-80
}

Received: 15 September 2019; Accepted: 21 October 2019; Published: 26 October 2019

\begin{abstract}
Ammonium $\left(\mathrm{NH}_{4}{ }^{+}\right)$and nitrate $\left(\mathrm{NO}_{3}{ }^{-}\right)$are the two forms of inorganic nitrogen essential for physiological and biochemical processes in higher plants, but little is known about how the $\mathrm{NH}_{4}{ }^{+}: \mathrm{NO}_{3}{ }^{-}$ ratio may affect nitrogen metabolism. This study determined the effect of $\mathrm{NH}_{4}{ }^{+}: \mathrm{NO}_{3}{ }^{-}$ratios on plant growth, accumulation, and distribution of nutrient elements, fruit quality, enzyme activity, and relative expression of genes involved in nitrogen $(\mathrm{N})$ metabolism in pepper (Capsicum annuит $\mathrm{L}$.). In a pod experiment, the $\mathrm{NH}_{4}{ }^{+}: \mathrm{NO}_{3}{ }^{-}$ratios of 0:100, 12.5:87.5, 25:75, 37.5:62.5, and 50:50 were arranged in a complete randomized design with three replicates. The application of $\mathrm{NH}_{4}{ }^{+}: \mathrm{NO}_{3}{ }^{-}$at $25: 75$ resulted in highest dry matter and $\mathrm{N}$, phosphorus $(\mathrm{P})$, and potassium $(\mathrm{K})$ accumulation. Pepper treated with 25:75 ratio increased root length, surface areas, and root volume and tips. The contents of vitamin C, soluble sugar, soluble protein, total phenols, flavonoids, and capsaicinoids in the fruits were significantly higher with the $\mathrm{NH}_{4}{ }^{+}: \mathrm{NO}_{3}{ }^{-}$ratio of 25:75 compared with 0:100 treatment, while lowering nitrate content was found in $\mathrm{NH}_{4}{ }^{+}: \mathrm{NO}_{3}{ }^{-}$ratios of 25:75, 37.5:62.5, and 50:50 treatments. Activity of glutamine synthetase (GS), glutamate synthases (GOGAT) enzyme and the levels of relative expression of genes coding these enzymes were superior when the $\mathrm{NH}_{4}{ }^{+}: \mathrm{NO}_{3}{ }^{-}$ratio of 25:75 were applied. Therefore, an appropriate ratio of $\mathrm{NH}_{4}{ }^{+}: \mathrm{NO}_{3}{ }^{-}(25: 75)$ in nitrogen application can stimulate root development, promote enzyme activities, and enhance the productivity and fruit quality in pepper.
\end{abstract}

Keywords: ammonium; capsaicin; glutamate synthases; glutamine synthetase; nitrite reductase; nitrogen metabolism; root morphology

\section{Introduction}

From the Green Revolution, new agricultural methods and technology rapidly increased application of synthetic fertilizer in crop production compared to the prior time. For example, the national average fertilizer application rate in China was $147 \mathrm{~kg} \mathrm{~N} \mathrm{ha}^{-1}$ year ${ }^{-1}$ in 2016, which was 6.3 times the rate used 50 years ago [1]. It is anticipated that the fertilizer use for agriculture worldwide will increase continuously to meet the food demands for growing population. Excessive use of nitrogen often results in the loss of more than half of the amount added through leaching or gaseous emission 
due to denitrification, leading to the pollution of air, water and soil, and the loss of biodiversity [2]. Therefore, minimizing nitrogen $(\mathrm{N})$ fertilizer inputs [3], and improving Nitrogen Utilization Efficiency (NUE) are a major challenge worldwide [4].

Ammonium $\left(\mathrm{NH}_{4}{ }^{+}\right)$and nitrate $\left(\mathrm{NO}_{3}{ }^{-}\right)$are the two predominant forms of inorganic nitrogen absorbed by the roots of higher plants in agricultural ecosystems [5], and these nitrogen forms exert different effects on biochemical processes in higher plants or soil environments. The absorption of nitrate nitrogen is accompanied by the uptake of inorganic cation and the release of $\mathrm{OH}^{-}$, whereas the ammonium nitrogen is accompanied by the absorption of inorganic anion and the release of $\mathrm{H}^{+}$ in rhizosphere environment [6]. Nitrate may account for a higher energy cost than ammonium due to the reduction of nitrate to ammonium in cells by two consecutive processes [7]. First, nitrate is reduced to nitrite by nitrate reductase (NR), then a reduction of the nitrite to ammonium by nitrite reductase (NiR), thereby the ammonium can produce a variety of amino acids, a process enhanced by glutamine synthetase (GS) and glutamate synthase (GOGAT) [8-10]. For the past few years, cereal yield increases have been achieved in some solution culture studies by controlling levels of nitrate and ammonium [11]. However, the $\mathrm{N}$ form is beneficial for plant growth, yield, and quality may vary with plant species [12-14] and many other factors [15-17]. Supplying the two forms of nitrogen in a specific ratio will lead to the optimum growth; this finding has been reported in species such as apple (Malus domestica Borkh) [18,19], tomato (Solanum lycopersicum L.) [20,21], and rice (Oryza sativa L.) [22-24]. Predominant sources of ammonia N may also negatively affect the whole plant biomass deposition in some species, such as Arabidopsis thaliana [25,26]; while in another study, Arabidopsis plants displayed the potential of stimulating glucosinolate metabolism with ammonium nutrition [27]. An appropriate ammonium-nitrate ratio can enhance plant tolerance to abiotic stresses. For example, compared with nitrate, the addition of moderate amount of ammonium alleviates low light intensity stress in some species, such as Chinese cabbage (Brassica pekinensis) [28]. $\mathrm{A} \mathrm{NH}_{4}{ }^{+}: \mathrm{NO}_{3}{ }^{-}$ ratio of 50:50 enhanced tomato growth, soluble protein in roots, and GS activity at chilling temperature $\left(5-18^{\circ} \mathrm{C}\right)$ [29].

There has been an increased trend that consumers demand for vegetables with high nutritional values and safe characteristics. Pepper (Capsicum annum L.) is an important source of nutrients such as vitamins $C$, proteins, and carbohydrates for human consumption. Also, capsaicin, dihydrocapsaicin and related compounds, namely capsaicinoids, are the secondary metabolites available in pepper fruits [30]. Thus, peppers are used as an important spice in various foods. Additionally, peppers have high medical value, as capsaicinoids are utilized for curing biological ailments and improving overall human health [31]. Two studies concern the impact of different $\mathrm{N}$ form supply on pepper fruit quality parameters, such as $\mathrm{N}$ and phosphorus (P) content [32], or nitrate, total $\mathrm{N}$ and soluble sugars content [33]. To the best of our knowledge, there is a lack of information regarding how those traits of hot peppers might be related to the way the crop is produced. In particular, little is known about how different forms of nitrogen applied to the crop may affect the levels of pungency in pepper fruits. We hypothesize that the supply of nitrogen in an appropriate ammonium to nitrate ratio will promote root development, improve nutrient absorption and enhance capsaicin and dihydrocapsaicin concentrations in pepper. The objectives of this study were to determine the effect of different $\mathrm{NH}_{4}{ }^{+}: \mathrm{NO}_{3}{ }^{-}$ratios on plant growth, root development, nutrient accumulation, and distribution in different tissues/organs, and identify the most appropriate $\mathrm{NH}_{4}{ }^{+}: \mathrm{NO}_{3}{ }^{-}$ratio for improved fruit quality, especially the pungency of hot pepper.

\section{Materials and Methods}

\subsection{Plant Material and Growth Condition}

Pepper (cv. 'Longjiao No.5') seeds obtained from the Gansu Academy of Agricultural Science in Lanzhou, China were used as the test material. The seeds were soaked in water at $55^{\circ} \mathrm{C}$ for $15 \mathrm{~min}$ with agitation and at $25^{\circ} \mathrm{C}$ for $8 \mathrm{~h}$, then placed under dark conditions at $28^{\circ} \mathrm{C}$ for 3 days 
to allow germination in an electronic climate box. The seedlings were grown in seedling trays for 40 days and then transplanted into plastic containers ( $25 \mathrm{~cm}$ in depth and $35 \mathrm{~cm}$ wide at the top) which were filled with $6 \mathrm{~L}$ of the mixture of vermiculite and quartz sand $(3: 1, v: v)$. The vermiculite (2-4 mm) and quartz sand (1-2 mm) were obtained from Xuyang Mining Company (Hebei, China). The physical and chemical properties of the vermiculite and quartz mixture are shown in Table 1. Each container contained two seedlings with a similar size. The experiment was conducted in a greenhouse at Gansu Agricultural University in Lanzhou ( $\left.36^{\circ} 05^{\prime} 39.86^{\prime \prime} \mathrm{N}, 103^{\circ} 42^{\prime} 31.09^{\prime \prime} \mathrm{E}\right)$. The conditions in the greenhouse were as follows: temperature of $28 \pm 2{ }^{\circ} \mathrm{C} / 18 \pm 2{ }^{\circ} \mathrm{C}$ (day/night), photoperiod of $12 \mathrm{~h}$, average photosynthetic active radiation at noon of $1000 \mu \mathrm{mol} \mathrm{m}^{-2} \mathrm{~s}^{-1}$, and relative humidity of $60-70 \%$.

Table 1. Physical and chemical properties of medium.

\begin{tabular}{|c|c|c|c|c|c|c|}
\hline Substrate & $\begin{array}{l}\text { Available N } \\
\left(\mathrm{mg} \mathrm{kg}^{-1}\right)\end{array}$ & $\begin{array}{c}\text { Available P } \\
\left(\mathrm{mg} \mathrm{kg}^{-1}\right)\end{array}$ & $\begin{array}{l}\text { Available K } \\
\left(\mathrm{mg} \mathrm{kg}^{-1}\right)\end{array}$ & $\begin{array}{c}\mathrm{EC} \\
\left(\mathrm{us} \mathrm{cm}^{-1}\right)\end{array}$ & $\begin{array}{l}\text { Bulk Density } \\
\quad\left(\mathrm{g} \mathrm{cm}^{-3}\right)\end{array}$ & $\mathrm{pH}$ \\
\hline $\begin{array}{l}\text { Vermiculite: quartz } \\
\text { sand }=3: 1\end{array}$ & 1.63 & 8.02 & 9.00 & 116.90 & 0.95 & 6.79 \\
\hline
\end{tabular}

Note: nitrogen (N); phosphorus (P); potassium (K).

\section{2. $\mathrm{NH}_{4}{ }^{+}: \mathrm{NO}_{3}{ }^{-}$Ratio and Experiment Design}

Plants with similar physical size were treated with five $\mathrm{NH}_{4}{ }^{+}: \mathrm{NO}_{3}{ }^{-}$ratios after being transplanted: $\mathrm{T} 1\left(\mathrm{NH}_{4}{ }^{+}: \mathrm{NO}_{3}{ }^{-}=0: 100\right)$ (as control), T2 $\left(\mathrm{NH}_{4}{ }^{+}: \mathrm{NO}_{3}{ }^{-}=12.5: 87.5\right), \mathrm{T} 3\left(\mathrm{NH}_{4}{ }^{+}: \mathrm{NO}_{3}{ }^{-}=25: 75\right), \mathrm{T} 4$ $\left(\mathrm{NH}_{4}{ }^{+}: \mathrm{NO}_{3}{ }^{-}=37.5: 62.5\right)$, and $\mathrm{T} 5\left(\mathrm{NH}_{4}{ }^{+}: \mathrm{NO}_{3}{ }^{-}=50: 50\right)$ (Table 2). Ammonium sulfate $\left[\left(\mathrm{NH}_{4}\right)_{2} \mathrm{SO}_{4}\right]$ was used as $\mathrm{NH}_{4}{ }^{+}$source. Potassium nitrate $\left(\mathrm{KNO}_{3}\right)$ and calcium nitrate tetrahydrate $\left[\mathrm{Ca}\left(\mathrm{NO}_{3}\right)_{2} \cdot 4 \mathrm{H}_{2} \mathrm{O}\right]$ were used as $\mathrm{NO}_{3}{ }^{-}$source. Monopotassium phosphate $\left(\mathrm{KH}_{2} \mathrm{PO}_{4}\right)$ was used as the source of $\mathrm{P}$. Potassium nitrate $\left(\mathrm{KNO}_{3}\right)$ and potassium phosphate monobasic $\left(\mathrm{KH}_{2} \mathrm{PO}_{4}\right)$ were used as the source of potassium $(\mathrm{K})$. All pepper plants were maintained under the concentrations of $\mathrm{N}(10 \mathrm{mM}), \mathrm{P}(1 \mathrm{mM})$, and $\mathrm{K}(6 \mathrm{mM})$. Also, microelements were supplied according to Hoagland and Arnon [34]. At the seedling, flowering, and fruiting stages, pepper plants were watered, respectively, with 500, 1000, and $1500 \mathrm{~mL}$ of five nutrition solutions per container at six days interval. An amount of $7 \mu \mathrm{mol} \mathrm{L} \mathrm{L}^{-1}$ of nitrification inhibitor was added to each container to prevent the nitrification of ammonium [35]. Each treatment had 48 containers arranged in a complete randomized design with three replicates; the sufficient number of plants allowed for the multiple samplings for various measurements. Of which, 36 containers in each treatment were used to determine plant traits and the other 12 containers were used to determine fruit quality and gene expression.

Table 2. The concentrations of elements $(\mathrm{mM}), \mathrm{pH}$, and EC in 5 nutrition solutions.

\begin{tabular}{|c|c|c|c|c|c|c|c|c|c|}
\hline \multirow{3}{*}{ Treatments } & \multirow{3}{*}{$\mathrm{NH}_{4}{ }^{+}: \mathrm{NO}_{3}{ }^{-}$} & \multicolumn{6}{|c|}{ Elements Concentration $\left(\mathrm{mmol} \mathrm{L}^{-1}\right)$} & \multirow{3}{*}{$\mathrm{pH}$} & \multirow{3}{*}{$\begin{array}{c}\text { EC } \\
(\mu \mathrm{s} / \mathrm{cm})\end{array}$} \\
\hline & & \multicolumn{2}{|c|}{$\mathbf{N}$} & \multirow{2}{*}{$\mathbf{P}$} & \multirow{2}{*}{$\mathbf{K}$} & \multirow{2}{*}{$\mathrm{Ca}$} & \multirow{2}{*}{$\mathrm{Mg}$} & & \\
\hline & & $\mathrm{NH}_{4}{ }^{+}-\mathrm{N}$ & $\mathrm{NO}_{3}{ }^{-}-\mathrm{N}$ & & & & & & \\
\hline $\mathrm{T} 1$ & $0: 100$ & 0 & 10 & 1 & 6 & 2.5 & 1 & 6.8 & 892 \\
\hline $\mathrm{T} 2$ & $12.5: 82.5$ & 1.25 & 8.25 & 1 & 6 & 2.5 & 1 & 6.7 & 884 \\
\hline $\mathrm{T} 3$ & $25: 75$ & 2.5 & 7.5 & 1 & 6 & 2.5 & 1 & 6.7 & 899 \\
\hline $\mathrm{T} 4$ & $37.5: 62.5$ & 3.75 & 6.25 & 1 & 6 & 2.5 & 1 & 6.6 & 881 \\
\hline T5 & $50: 50$ & 5 & 5 & 1 & 6 & 2.5 & 1 & 6.7 & 898 \\
\hline
\end{tabular}

Note: ammonium $\left(\mathrm{NH}_{4}{ }^{+}\right)$; nitrate $\left(\mathrm{NO}_{3}{ }^{-}\right)$; nitrogen $(\mathrm{N})$; phosphorus $(\mathrm{P})$; potassium $(\mathrm{K})$; calcium $(\mathrm{Ca})$; magnesium $(\mathrm{Mg})$.

\subsection{Dry Matter Determination}

At $0,30,60,90$ and 120 days after transplantation (DAT), 6 plants were randomly selected from each replicate. The roots were washed with distilled water and separated from the shoots. Both root, stem, leaf, and fruit samples were dried separately at $105^{\circ} \mathrm{C}$ for $15 \mathrm{~min}$ and further dried at $80^{\circ} \mathrm{C}$ until 
a constant weight, and weighed for dry biomass [36]. Calculate the plant dry matter increment every 30 days to get dry matter accumulation rate as the follow formula:

$$
\text { Dry matter accumulation rate }\left(\mathrm{g} \mathrm{plant}^{-1} \mathrm{~d}^{-1}\right)=\frac{\left(\mathrm{M}_{\mathrm{t}}-\mathrm{M}_{0}\right)}{\mathrm{D}}
$$

where $\mathrm{M}_{\mathrm{t}}$ and $\mathrm{M}_{0}$ are dry matter at the current and previous sampling, respectively, $\mathrm{D}$ is the number of days between the current and the previous sampling.

\subsection{Analysis of Root Morphology}

The cleaned roots from each replicate were placed in transparent trays with distilled water gently to make them fully dispersed. Images were obtained using a root scanner (STD 4800, EPSON, Canada) and data were analyzed using Win RHIZO version 5.0 (Regent Instruments, Inc., Quebec City, QC, Canada).

\subsection{Determination of $N, P, K$ Contents}

At 30, 60, 90, and $120 \mathrm{DAT}$, the various plant parts which had been used to determine dry matter (described above), were grounded and sieved through a $2.0 \mathrm{~mm}$ screen. $\mathrm{H}_{2} \mathrm{SO}_{4}$ and $\mathrm{H}_{2} \mathrm{O}_{2}$ were used to mineralize the powder until transparent and colorless liquids were observed, which were prepared to determine $\mathrm{N}, \mathrm{P}$, and $\mathrm{K}$. Total $\mathrm{N}$ was measured using Kjeldahl method with a full-automatic Kjeldahl apparatus K1100 (Jinan Hanon Instruments Company, Jinan, China) [37]. Total P contents were measured using molybdenum blue colorimetric method and analyzed using a TU-1900 spectrophotometer (Beijing Persee Instruments Company, Beijing, China) [38]. Flame photometer AP1302 (Shanhai Aopu Analytical Instruments Company, Shanghai, China) was used for the assay of total $\mathrm{K}$ contents [39]. We used the formulas below in our calculations to get nutrient accumulation and distribution:

$$
\begin{aligned}
& \text { The accumulation of N, P and K of organ }\left(\mathrm{g} \mathrm{plant}^{-1} \mathrm{DW}\right)=\mathrm{C} \times \mathrm{W} \\
& \text { The distribution of N, P or K of organ }(\%)=\frac{\mathrm{C} \times W}{\mathrm{~A}} \times 100 \%
\end{aligned}
$$

in which $\mathrm{C}$ is the content of $\mathrm{N}, \mathrm{P}$ and $\mathrm{K}$ of organ $\left(\mathrm{g} \mathrm{kg}^{-1} \mathrm{DW}\right), \mathrm{W}$ is the dry weight of organ (kg plant ${ }^{-1}$ $\mathrm{DW}), \mathrm{A}$ is the total content of $\mathrm{N}, \mathrm{P}$ or K in one plant (g plant $\left.{ }^{-1} \mathrm{DW}\right)$.

\subsection{Determination of Nitrate, Vitamin C, Soluble Sugar, Soluble Protein, Total Phenol, and Flavonoid Contents}

Mature green, ripening, and red fruits were harvested from 12 randomly selected containers from each treatment, with three independent replicates, were washed with distilled water and store at $-80{ }^{\circ} \mathrm{C}$ for the determination of quality parameters. Nitrate content was measured using the salicylic acid-sulfuric acid method [40], vitamin C content was measured using the 2,6-dichloroindophenol stain method [41], anthrone-sulfuric acid assay method was used to estimate soluble sugar [42], and coomassie brilliant blue method for the estimation of soluble protein content [43]. The total phenol and flavonoid content were extracted with methanol containing $0.01 \% \mathrm{HCl}$, a slight modification of the method published elsewhere [44].

\subsection{Determination of Capsaicin and Dihydrocapsaicin Contents}

Mature green, ripening, and red fruits from 12 randomly selected containers from each treatment, with three independent replicates, were washed with distilled water and then dried at $50{ }^{\circ} \mathrm{C}$ in an oven until a constant weight. Methanol-tetrahydrofuran (1:1, v:v) was added to the crushed fruit powder sample ( $1 \mathrm{~g}$, accurate to 0.0001) and extracted using a temperature-controlled ultrasonic cleaner SB25-12D (Ningbo Scientz Biotech Company, Ningbo, China) at $60{ }^{\circ} \mathrm{C}$ for $0.5 \mathrm{~h}$, repeated three times. The supernatant was concentrated using a rotary evaporator RE52CS (Shanghai Yarong Instruments Company, Shanghai, China) at $70^{\circ} \mathrm{C}$ for $5 \mathrm{~min}$. The concentrated solution was diluted 
with methanol-tetrahydrofuran $(1: 1, v: v)$ solution. Prior to injection, samples were filtered through a Millipore membrane of $0.22 \mu \mathrm{m}$ pore size [45].

Preparation of standard solution: capsaicin (Sigma-Aldich, St. Louis, MO, USA, 98\%) and dihydrocapsaicin (Sigma-Aldich, St. Louis, MO, USA, 98\%) were accurately weighted and dissolved in methanol with a concentration of $1 \mathrm{mg} \mathrm{mL}^{-1}$. A series of solutions of $0,20,40,60,80$, and $100 \mu \mathrm{g} \mathrm{mL}^{-1}$ were prepared with the mixed standard solution.

High performance liquid chromatography (HPLC) analysis: The chromatographic system consisted of Shimadzu LC-20A HPLC (Kyoto, Japan) with ZORBAX Eclipse Plus $\mathrm{C}_{18}$ column $(250 \mathrm{~mm} \times 4.6 \mathrm{~mm} \times 5.0 \mu \mathrm{m})$. The absorbance at $280 \mathrm{~nm}$ was measured using a Shimadzu UV-VIS 1700 spectrophotometer. Methanol- $\mathrm{H}_{2} \mathrm{O}(55: 45)$ was used as the mobile phase with a flow rate of $1.0 \mathrm{~mL} \mathrm{~min}{ }^{-1}$. Methanol and tetrahydrofuran were of HPLC grade, and ultrapure water was used for HPLC determination.

The pungency of pepper was calculated by using Scoville Heat Units (SHU) with the following equation [46]:

$$
\mathrm{SHU}=\left(X_{1}+X_{2}\right) \times\left(16.1 \times 10^{3}\right)+\left(X_{1}+X_{2}\right) / 90 \% \times 10 \% \times\left(9.3 \times 10^{3}\right)
$$

in the formula, $X_{1}$ and $X_{2}$ represent the contents of capsaicin and dihydrocapsaicin $\left(\mathrm{mg} \mathrm{g}^{-1}\right)$, respectively, $90 \%$ represents the ratio of capsaicin and dihydrocapsaicin in capsaicinoids, $16.1 \times 10^{3}$ represents capsaicin and dihydrocapsaicin in SHU, and $9.3 \times 10^{3}$ represents capsaicinoids in SHU.

\subsection{The Determination of NR, NiR, GS and GOGAT Activity}

At 30, 60, 90 and 120 DAT, the second fully expanded leaves were sampled from each replicate, frozen in liquid nitrogen and stored at $-80^{\circ} \mathrm{C}$. To determine the activity of Nitrate reductase (NR), $0.5 \mathrm{~g}$ leaves were ground in liquid nitrogen and added extraction buffer $(0.025 \mathrm{M}$ phosphate buffer, $\mathrm{pH} 8.7$, $0.1 \mathrm{mM}$ EDTA, $1 \mathrm{mM}$ cysteine) to the leaf tissue powder. Following centrifugation $\left(4^{\circ} \mathrm{C}, 12000 \mathrm{~g}\right.$, $15 \mathrm{~min}), \mathrm{NR}$ activity was measured immediately in the supernatant. The reaction mixture consisted of $0.1 \mathrm{M}$ phosphate buffer (pH7.5) and 0.17 $\mathrm{mM}$ NADH. The reaction was terminated after $30 \mathrm{~min}$ by the addition of $1 \mathrm{~mL}$ of $1 \%$ sulfanilamide $((w / v)$ in $3 \mathrm{~mol} / \mathrm{L} \mathrm{HCl})$ and then naphthylethylenediamine dihydrochloride $(0.02 \%(w / v))$ to the reaction mixture, and measured at $540 \mathrm{~nm}[47,48]$. For the determination of NiR, GS, and GOGAT, tissues were ground to powder in a mortar that had been pre-cooled with liquid nitrogen and then homogenized in the extraction buffer ( $0.1 \mathrm{M}$ phosphate buffer, pH7.5). The activity of NiR was monitored with the kit NIR-2-G at $540 \mathrm{~nm}$, the GS was assessed using GS kit (GS-2-Y) at $540 \mathrm{~nm}$, and the GOGAT activity was determined by GOGAT detection kit (GOGAT-2-Y) at $340 \mathrm{~nm}$ [49]. The kits for analyzing enzyme activities were purchased from Comin Biotechnology Co. Ltd., Suzhou, China.

\subsection{RNA Extraction and Gene Expression Analysis}

RNA samples were extracted at $60 \mathrm{~d}$ using a RNA extraction Kit (Tiangen, Beijing, China) in accordance with the manufacturer's instructions. After extraction, RNA quality and quantity were assessed using an Agilent 2100 spectrophotometer (Agilent Technologies, Santa Clara, CA, USA). Total RNA was incubated at $42{ }^{\circ} \mathrm{C}$ for 3 min with gDNA Eraser (Tiangen, Beijing, China) to remove genomic DNA contamination, the first strand cDNA used as a template for qRT-PCR was synthesized from 0.5-2 $\mu \mathrm{g}$ of the total RNA using an oligo $(\mathrm{dT})_{18} 10 \mathrm{mM}$ first-strand cDNA synthesis Kit (TaKaRa, Dalian, China). Finally, cDNA was diluted 5-fold with sterile $\mathrm{ddH}_{2} \mathrm{O}$, and $1 \mu \mathrm{L}$ of cDNA was used for quantitative real-time PCR (qRT-PCR) analysis.

The pepper actin gene (GenBank accession No. XM_016722297.1) was used as an internal control. On the basis of nucleotide, the primers for capsicum annuum nitrate reductase (NR-1, $N R-2)$, nitrite reductase (NiR), glutamine synthetase (chloroplastic) (GS-1), glutamine synthetase (GS-2), ferredoxin-dependent glutamate synthase (GOGAT-1), NADH-dependent glutamate synthase (GOGAT-2) and actin genes were designed by TakaRa Biotechnology Co., Ltd. (Dalian, China) and the 
sequences were provided in Table 3. Quantitative real-time polymerase chain reaction (qRT-PCR) was performed to determine the relative transcript level of each CDNA, with a real-time PCR detection system (Lightcycler96 Real-Time PCR System, Roche). Each reaction system was performed in a final volume of $20 \mu \mathrm{L}$, consisted of $2 \times \mathrm{SYBR}$ Green Master Mix, $1 \mu \mathrm{L}$ of diluted cDNA, $0.8 \mu \mathrm{M}$ of forward

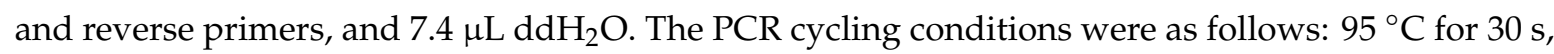
followed by 40 cycles of $95^{\circ} \mathrm{C}$ for $10 \mathrm{~s}$, and $60^{\circ} \mathrm{C}$ for $30 \mathrm{~s}$. The fluorescence data were collected during the annealing step. All qRT-PCR for each gene was performed in three biological replicates, the relative quantification of mRNA levels is based on the method of Livak and Schmittgen [50].

Table 3. The list of primer sequences and Gene Bank accession number used in this study for the qRT-PCR.

\begin{tabular}{|c|c|c|c|}
\hline Gene Name & Sequence $\left(5^{\prime}-3^{\prime}\right)$ & Accession Number & Amplicon (bp) \\
\hline$N R-1$ & $\begin{array}{l}\text { F:TGACGCTGAACTTGCAAACG } \\
\text { R:CCTCAACGTGTAAGGTCGCT }\end{array}$ & XM_016714485.1 & $151 \mathrm{bp}$ \\
\hline$N R-2$ & $\begin{array}{l}\text { F:GATGACGACGACACGTCGAG } \\
\text { R:AGCGGTTCCTTCGTCTCTTG }\end{array}$ & XM_016714486.1 & $129 \mathrm{bp}$ \\
\hline NIR & $\begin{array}{l}\text { F:TCAGAATCAGCTCGTGGCTT } \\
\text { R:GCATCGTGGAATGTCACACA }\end{array}$ & AF065616.1 & $172 \mathrm{bp}$ \\
\hline GS-1 & $\begin{array}{c}\text { F:TGAAGCTCTTGCTGCCCAAA } \\
\text { R:TGGCTCCTTTACAAGATTTTCCCA }\end{array}$ & NM_001324595.1 & $154 \mathrm{bp}$ \\
\hline GS-2 & $\begin{array}{l}\text { F:GGAAGGGACACAGAGAAGGC } \\
\text { R:AACAAGCGATCCTTCGAGCA }\end{array}$ & XM_016717075.1 & $160 \mathrm{bp}$ \\
\hline GAGOOT-1 & $\begin{array}{l}\text { F:TGACCGTGCTGTATGTGGTC } \\
\text { R:GCCCAGCACTCCCAGTAAAT }\end{array}$ & NM_001324694.1 & $104 \mathrm{bp}$ \\
\hline GAGOOT-2 & $\begin{array}{l}\text { F:GATGGGGTTCCTTGGTCCTG } \\
\text { R:GTCCCCTACGACAGTCTCCT }\end{array}$ & XM_016700960 & $143 \mathrm{bp}$ \\
\hline Actin & $\begin{array}{c}\text { F:GTCCTTCCATCGTCCACAGG } \\
\text { R:GAAGGGCAAAGGTTCACAACA }\end{array}$ & XM_016722297.1 & $133 \mathrm{bp}$ \\
\hline
\end{tabular}

\subsection{Statistical Analysis}

The analysis of variance was performed using SPSS 17.0 for Windows (Chicago, USA). The data presented was mean $\pm \mathrm{SE}$ of three replicates for each treatment. A two-way analysis of variance (ANOVA) with $\mathrm{NH}_{4}{ }^{+}: \mathrm{NO}_{3}{ }^{-}$ratio treatment and days after transplantation was used to assess the overall variability of dry matter, root morphology, nutrient accumulation, fruit quality and enzymes activity. Significant difference and interactions were further evaluated with the Newman Keul post-hoc test (SNK). The data of nutrient distribution and gene expression were analyzed with a one-way ANOVA with treatment as variable. The differences were considered significant at $p<0.05$.

\section{Results}

\subsection{Dry Matter Accumulation and Root Morphology}

The amounts of dry matter in the shoot (Figure 1A) and root (Figure 1B) significantly increased from 0 to 120 DAT $(p<0.05)$ and the trend of change varied with the $\mathrm{NH}_{4}{ }^{+}: \mathrm{NO}_{3}{ }^{-}$ratios. The increase in the $\mathrm{NH}_{4}{ }^{+}$concentration did not affect shoot and root dry matter at 30 DAT $(p>0.05)$. However, at $120 \mathrm{DAT}$, dry matter of root and shoot were observed significant increases in plants with $12.5-37.5 \%$ $\mathrm{NH}_{4}{ }^{+}$concentrations (T2, T3, and T4). The rate of dry matter (aboveground + root) accumulation significantly increased $(p<0.05)$ with days after transplantation for all treatments, and they reached the peak at Day 90 except T5 $\left(\mathrm{NH}_{4}{ }^{+}: \mathrm{NO}_{3}{ }^{-}=50: 50\right)$ which had the peak value at Day 120 (Figure 1C). Among the five treatments, $\mathrm{T} 2\left(\mathrm{NH}_{4}{ }^{+}: \mathrm{NO}_{3}{ }^{-}=12.5: 37.5\right)$ had the significant highest dry matter accumulation rate $(p<0.05)$ compared to the other treatments at Day 90. At Day $120, \mathrm{~T} 1\left(\mathrm{NH}_{4}{ }^{+}: \mathrm{NO}_{3}{ }^{-}=0: 100\right)$ had the lowest rate among treatments. 


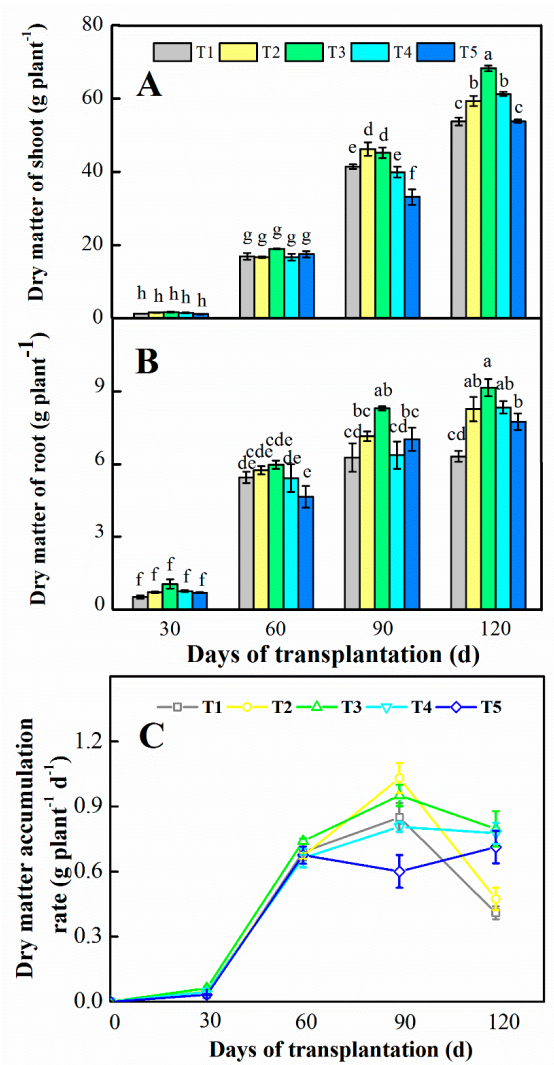

Figure 1. Dry matter of the shoot (A), root (B) and dynamic changes of dry matter accumulation rate $(C)$ of pepper plants as affected by different $\mathrm{NH}_{4}{ }^{+}: \mathrm{NO}_{3}{ }^{-}$ratios. $\mathrm{T} 1\left(\mathrm{NH}_{4}{ }^{+}: \mathrm{NO}_{3}{ }^{-}=0: 100\right)$, T2 $\left(\mathrm{NH}_{4}{ }^{+}: \mathrm{NO}_{3}{ }^{-}=12.5: 87.5\right), \mathrm{T} 3\left(\mathrm{NH}_{4}{ }^{+}: \mathrm{NO}_{3}{ }^{-}=25: 75\right), \mathrm{T} 4\left(\mathrm{NH}_{4}{ }^{+}: \mathrm{NO}_{3}{ }^{-}=37.5: 62.6\right)$, and $\mathrm{T} 5$ $\left(\mathrm{NH}_{4}{ }^{+}: \mathrm{NO}_{3}{ }^{-}=50: 50\right)$. Vertical bars represent mean $\pm \mathrm{SE}(n=3$, each replicate consisted of 6 pepper plants) and the different letters of $(\mathbf{A})$ and $(\mathbf{B})$ denote significant differences $(p<0.05)$.

When treated with five ratios, the plants showed no differences in root morphological characteristics including total root length, surface area, volume and the number of root tips $(p>0.05)$ at 30 DAT (Figure 2). The total root length in ratio of $\mathrm{NH}_{4}{ }^{+}: \mathrm{NO}_{3}{ }^{-}=25: 75$ (T3) had significant difference with that in $\mathrm{T} 1\left(\mathrm{NH}_{4}{ }^{+}: \mathrm{NO}_{3}{ }^{-}=0: 100\right)$ treatment at 60,90, and 120 DAT $(p<0.05)$ (Table 4$)$. The highest value of root surface area in T3 was 32.8\% higher than T1 at 120 Day. Beyond that, surface area was significantly higher in T3 compared with T1 and T5 at Day $90(p<0.05)$. At Day 120, the root volume presented the highest value in T3, which was $52.8 \%, 27.1 \%, 14.8 \%, 40.6 \%$ higher than T1, T2, T4 $\left(\mathrm{NH}_{4}{ }^{+}: \mathrm{NO}_{3}{ }^{-}=37.5: 62.5\right)$, and T5. Moreover, the root tips of T3 showed significant differences $(p<0.05)$ with $100 \%$ nitrate treated plants (T1) except 30 Day. Overall, ammonium-nitrate ratio at 25:75 enhanced root growth and development more than the single nitrate treatment at 60, 90, and 120 DAT.
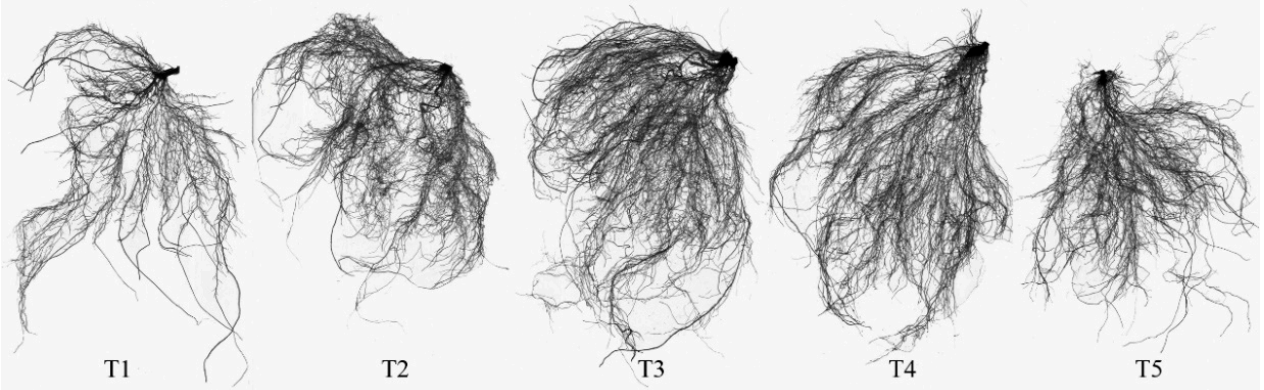

Figure 2. Architecture characteristics of pepper roots 30 days after transplantation as affected by different $\mathrm{NH}_{4}{ }^{+}: \mathrm{NO}_{3}{ }^{-}$ratios. 
Table 4. Effects of $\mathrm{NH}_{4}{ }^{+}: \mathrm{NO}_{3}{ }^{-}$ratios on root morphological parameters of pepper.

\begin{tabular}{|c|c|c|c|c|c|c|}
\hline Variables & DAT & T1 & $\mathrm{T} 2$ & T3 & $\mathrm{T} 4$ & T5 \\
\hline \multirow{4}{*}{ Total root length $\left(\mathrm{cm}\right.$ plant $\left.{ }^{-1}\right)$} & 30 & $2082.43 \pm 84.37 \mathrm{f}$ & $2383.06 \pm 69.03 \mathrm{f}$ & $2654.37 \pm 154.07 \mathrm{f}$ & $2689.63 \pm 96.74 \mathrm{f}$ & $2268.78 \pm 144.23 \mathrm{f}$ \\
\hline & 60 & $4568.28 \pm 391.46 \mathrm{e}$ & $4744.46 \pm 174.55 \mathrm{e}$ & $6140.96 \pm 445.39 \mathrm{~cd}$ & $5220.4 \pm 293.51 \mathrm{de}$ & $4751.35 \pm 137.36 \mathrm{e}$ \\
\hline & 90 & $6160.58 \pm 32.65 \mathrm{~cd}$ & $6730.50 \pm 125.78 \mathrm{bc}$ & $7844.17 \pm 226.66 \mathrm{ab}$ & $7584.07 \pm 192.30 \mathrm{abc}$ & $6977.53 \pm 273.40 \mathrm{bc}$ \\
\hline & 120 & $6607.17 \pm 276.91 \mathrm{bcd}$ & $8000.54 \pm 983.60 \mathrm{ab}$ & $8693.94 \pm 410.14 \mathrm{a}$ & $8080.38 \pm 355.26 \mathrm{ab}$ & $6581.64 \pm 555.74 \mathrm{bcd}$ \\
\hline \multirow{4}{*}{ Surface area $\left(\mathrm{cm}^{2}\right.$ plant $\left.^{-1}\right)$} & 30 & $302.15 \pm 15.53 \mathrm{~h}$ & $371.34 \pm 23.75 \mathrm{gh}$ & $413.98 \pm 40.98 \mathrm{fgh}$ & $402.97 \pm 29.89 \mathrm{fgh}$ & $360.13 \pm 30.11 \mathrm{gh}$ \\
\hline & 60 & $488.71 \pm 51.03 \mathrm{efg}$ & $502.04 \pm 20.69 \mathrm{efg}$ & $644.10 \pm 52.44 \mathrm{de}$ & $564.17 \pm 22.88$ ef & $503.08 \pm 13.88 \mathrm{efg}$ \\
\hline & 90 & $625.91 \pm 27.89 \mathrm{de}$ & $749.46 \pm 36.28 \mathrm{~cd}$ & $959.95 \pm 69.43 b$ & $844.14 \pm 25.39 b c$ & $758.00 \pm 37.51 \mathrm{~cd}$ \\
\hline & 120 & $859.78 \pm 24.74 b c$ & $990.17 \pm 26.35 b$ & $1141.94 \pm 30.81 \mathrm{a}$ & $1008.91 \pm 41.10 b$ & $881.55 \pm 104.36 b c$ \\
\hline \multirow{4}{*}{ Volume $\left(\mathrm{cm}^{3}\right.$ plant $\left.^{-1}\right)$} & 30 & $3.59 \pm 0.16 \mathrm{i}$ & $4.62 \pm 0.10 \mathrm{i}$ & $5.16 \pm 0.23 \mathrm{i}$ & $4.82 \pm 0.42 \mathrm{i}$ & $4.56 \pm 0.18 \mathrm{i}$ \\
\hline & 60 & $9.38 \pm 0.49 \mathrm{hi}$ & $12.01 \pm 0.58 \mathrm{gh}$ & $18.31 \pm 1.18$ ef & $14.01 \pm 0.59 \mathrm{fgh}$ & $12.93 \pm 0.46 \mathrm{fgh}$ \\
\hline & 90 & $13.76 \pm 1.12 \mathrm{fgh}$ & $19.53 \pm 0.85 \mathrm{de}$ & $27.97 \pm 1.55 b$ & $27.27 \pm 1.29 \mathrm{bc}$ & $17.31 \pm 0.60$ efg \\
\hline & 120 & $21.89 \pm 1.77$ cde & $26.32 \pm 3.77 b c$ & $33.44 \pm 0.53 \mathrm{a}$ & $29.14 \pm 2.54 b$ & $23.78 \pm 2.70 \mathrm{bcd}$ \\
\hline \multirow{4}{*}{ Tips (plant ${ }^{-1}$ ) } & 30 & $1605.00 \pm 106.64 \mathrm{~g}$ & $1673.25 \pm 128.78 \mathrm{~g}$ & $1724.00 \pm 70.62 \mathrm{~g}$ & $2248.67 \pm 185.87 \mathrm{~g}$ & $1359.25 \pm 77.53 \mathrm{~g}$ \\
\hline & 60 & $3875.83 \pm 88.27 \mathrm{f}$ & $4145.83 \pm 321.47 \mathrm{ef}$ & $5656.67 \pm 294.22$ cde & $4880.00 \pm 436.42 \mathrm{def}$ & $4168.33 \pm 277.24 \mathrm{ef}$ \\
\hline & 90 & $5074.17 \pm 555.98$ def & $6135.83 \pm 567.11 \mathrm{bcd}$ & $7592.50 \pm 255.80 \mathrm{ab}$ & $7040.00 \pm 861.57 \mathrm{abc}$ & $5529.17 \pm 291.68$ cde \\
\hline & 120 & $5952.33 \pm 255.48 \mathrm{bcd}$ & $7123.00 \pm 551.53 \mathrm{abc}$ & $7866.83 \pm 651.60 a$ & $7442.83 \pm 224.39 \mathrm{ab}$ & $6570.83 \pm 248.04 \mathrm{abcd}$ \\
\hline
\end{tabular}

Note: ammonium $\left(\mathrm{NH}_{4}{ }^{+}\right)$; nitrate $\left(\mathrm{NO}_{3}{ }^{-}\right)$. Values given are means $\pm \mathrm{SE}(n=3$ replicates with 6 plants per replicate). Significant differences $(p<0.05)$ were indicated by different letters for each variable. The treatment details were defined in Table 2. 


\subsection{N, P, and K Accumulation and Distribution Among Organs}

The accumulation of N P and K in the pepper plants (Figure 3A-C) increased significantly $(p<0.05)$ over the growth period. Within the first $60 \mathrm{~d}$ of growth after transplantation, nutrient elements were accumulated in the five treatments with no difference $(p>0.05)$. As the growth progressed to the reproductive period from 60 to $120 \mathrm{DAT}$, more nutrient elements were accumulated in the fruits than in the leaves, stems and roots, as more photosynthates were translocated from vegetative tissues to reproductive organs. Increasing ammonium concentration from 0 to 25 resulted in increased accumulation of $\mathrm{N}, \mathrm{P}$, and $\mathrm{K}$ in the plants. However, further increase in ammonium concentration from 25 to 50 led to a decrease in nutrient elements accumulation. At 120 DAT of data measurement, plants under T3 $\left(\mathrm{NH}_{4}{ }^{+}: \mathrm{NO}_{3}{ }^{-}=25: 75\right)$ had the highest total $\mathrm{N}$, which was $29.0 \%$ higher than $\mathrm{T} 1$ $\left(\mathrm{NH}_{4}{ }^{+}: \mathrm{NO}_{3}{ }^{-}=0: 100\right)$; the accumulation of $\mathrm{P}$ in $\mathrm{T} 3\left(0.334 \mathrm{~g} \mathrm{plant}^{-1} \mathrm{DW}\right)$ was significantly greater than the other treatments $(p<0.05)$; T3 and T4 gave the highest $\mathrm{K}$ values of 1.58 , and $1.56 \mathrm{~g} \mathrm{plant}^{-1}$ DW, respectively.
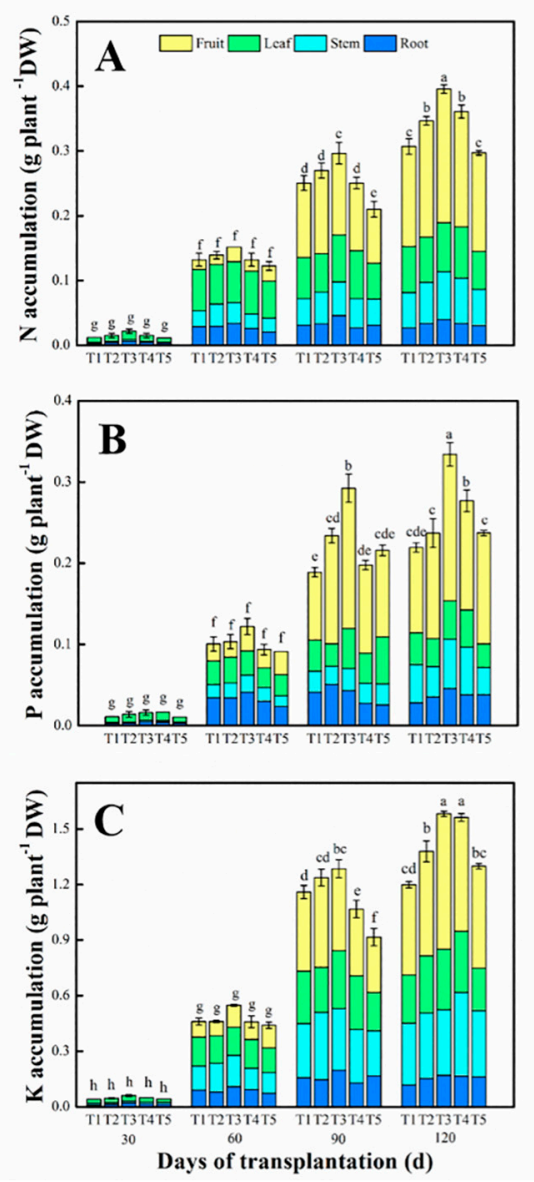

Figure 3. Total $\mathrm{N}(\mathbf{A}), \mathrm{P}(\mathbf{B})$, and $\mathrm{K}(\mathbf{C})$ accumulation in the root, stem, leaf and fruit of pepper plants as affected by different $\mathrm{NH}_{4}{ }^{+}: \mathrm{NO}_{3}{ }^{-}$ratios. Vertical bars represent mean $\pm \mathrm{SE}$ from three independent replicates and the different letters denote significant differences $(p<0.05)$. The five treatments were defined in Figure 1 above.

Percent distribution of $\mathrm{N}, \mathrm{P}$, and $\mathrm{K}$ differed in pepper plants under the various ammonium-nitrate ratios treatments (Table 5). Overall, the percent distribution of $\mathrm{N}$ in the different organs followed the order: root $<$ stem $<$ leaf $<$ fruit, whereas that of $\mathrm{P}$ in those organs were as follows: root $<$ leaf $<$ stem $<$ fruit, a trend similar to $\mathrm{K}$. On average, about half of N, P, and $\mathrm{K}$ were distributed in fruits and the rest were distributed in the other three organs. The $\mathrm{N}, \mathrm{P}$, and $\mathrm{K}$ distribution rate was least in the root when $\mathrm{NH}_{4}{ }^{+}: \mathrm{NO}_{3}{ }^{-}=0: 100$ (T1) was applied, whereas the distribution in the leaves was least with the 
application of $\mathrm{NH}_{4}{ }^{+}: \mathrm{NO}_{3}{ }^{-}=50: 50$ (T5). The distribution of the nutrient elements in stems did not differ among the five treatments with a few exceptions.

Table 5. Effects of $\mathrm{NH}_{4}{ }^{+}: \mathrm{NO}_{3}{ }^{-}$ratios on $\mathrm{N}, \mathrm{P}$ and $\mathrm{K}$ distribution in the different pepper organs $120 \mathrm{~d}$ after transplantation.

\begin{tabular}{|c|c|c|c|c|c|}
\hline \multirow{2}{*}{ Elements } & \multirow{2}{*}{ Treatments } & \multicolumn{4}{|c|}{ Percent Distribution (\%) of Nutrients in the Organ } \\
\hline & & Root & Stem & Leaf & Fruit \\
\hline \multirow{5}{*}{$\mathrm{N}$} & $\mathrm{T} 1$ & $8.69 \pm 0.27 b$ & $17.85 \pm 0.73 \mathrm{a}$ & $23.19 \pm 0.36 a$ & $50.27 \pm 0.45 a$ \\
\hline & $\mathrm{T} 2$ & $9.69 \pm 0.42 \mathrm{a}$ & $18.31 \pm 0.48 \mathrm{a}$ & $20.16 \pm 0.87 b$ & $51.83 \pm 1.46 \mathrm{a}$ \\
\hline & $\mathrm{T} 3$ & $10.00 \pm 0.11 \mathrm{a}$ & $18.77 \pm 0.24 \mathrm{a}$ & $19.08 \pm 0.54 b$ & $52.18 \pm 1.26 \mathrm{a}$ \\
\hline & $\mathrm{T} 4$ & $9.31 \pm 0.02 \mathrm{ab}$ & $19.45 \pm 0.38 \mathrm{a}$ & $21.93 \pm 0.45 \mathrm{ab}$ & $49.32 \pm 2.29 \mathrm{a}$ \\
\hline & T5 & $10.11 \pm 0.22 \mathrm{a}$ & $18.95 \pm 0.74 \mathrm{a}$ & $19.69 \pm 1.59 \mathrm{~b}$ & $51.24 \pm 2.00 \mathrm{a}$ \\
\hline \multirow{5}{*}{$\mathrm{P}$} & $\mathrm{T} 1$ & $12.78 \pm 0.12 \mathrm{c}$ & $21.22 \pm 3.32 \mathrm{a}$ & $17.93 \pm 1.12 \mathrm{a}$ & $48.13 \pm 1.48 c$ \\
\hline & $\mathrm{T} 2$ & $15.02 \pm 0.92 \mathrm{ab}$ & $15.78 \pm 0.94 \mathrm{ab}$ & $14.70 \pm 1.56 \mathrm{ab}$ & $54.50 \pm 0.9 \mathrm{ab}$ \\
\hline & $\mathrm{T} 3$ & $13.67 \pm 0.37 b c$ & $18.21 \pm 0.35 \mathrm{ab}$ & $14.14 \pm 0.63 \mathrm{ab}$ & $53.97 \pm 0.58 \mathrm{ab}$ \\
\hline & $\mathrm{T} 4$ & $13.66 \pm 1.01 \mathrm{bc}$ & $21.42 \pm 1.50 \mathrm{a}$ & $16.8 \pm 2.67 a b$ & $51.46 \pm 1.8 \mathrm{bc}$ \\
\hline & T5 & $16.11 \pm 0.34 \mathrm{a}$ & $14.12 \pm 0.89 b$ & $12.23 \pm 1.42 \mathrm{~b}$ & $57.49 \pm 1.49 a$ \\
\hline \multirow{5}{*}{$\mathrm{K}$} & $\mathrm{T} 1$ & $9.80 \pm 0.26 b$ & $27.85 \pm 1.01 \mathrm{a}$ & $21.66 \pm 0.24 a$ & $40.69 \pm 1.02 b$ \\
\hline & $\mathrm{T} 2$ & $10.96 \pm 0.22 \mathrm{ab}$ & $25.79 \pm 1.32 \mathrm{ab}$ & $22.36 \pm 0.17 \mathrm{a}$ & $40.89 \pm 1.25 b$ \\
\hline & $\mathrm{T} 3$ & $10.75 \pm 0.89 b$ & $22.37 \pm 0.83 b$ & $20.72 \pm 1.43 \mathrm{ab}$ & $46.15 \pm 1.36 \mathrm{a}$ \\
\hline & $\mathrm{T} 4$ & $10.43 \pm 0.23 b$ & $28.65 \pm 0.24 \mathrm{a}$ & $20.81 \pm 1.47 \mathrm{ab}$ & $40.12 \pm 1.57 b$ \\
\hline & $\mathrm{T} 5$ & $12.36 \pm 0.37 \mathrm{a}$ & $27.53 \pm 1.78 \mathrm{a}$ & $17.79 \pm 1.32 \mathrm{~b}$ & $42.32 \pm 1.11 \mathrm{ab}$ \\
\hline
\end{tabular}

Note: nitrogen (N); phosphorus (P); potassium (K). Values given are means \pm SE $(n=3$ replicates with 6 plants per replicate). Significant differences $(p<0.05)$ among treatments were indicated by different letters. The five treatments were defined in Table 2 above.

\section{3. $\mathrm{NH}_{4}{ }^{+}: \mathrm{NO}_{3}{ }^{-}$Ratios and Fruit Quality}

The different $\mathrm{NH}_{4}{ }^{+}: \mathrm{NO}_{3}{ }^{-}$ratios significantly $(p<0.05)$ affected the quality of the pepper fruits (Table 6). The nitrate content in fruits decreased with the increased ammonium concentration of the $\mathrm{NH}_{4}{ }^{+}: \mathrm{NO}_{3}{ }^{-}$ratios. The fruits from plants subjected to T1 supplied with $100 \%$ nitrate nitrogen, had significantly higher nitrate content than fruits with $\mathrm{T} 3$, T4, and T5.

The contents of soluble sugar, soluble protein, and dry matter in pepper fruits followed a similar trend of treatment effect where the fruits from plants supplied with $\mathrm{NH}_{4}{ }^{+}: \mathrm{NO}_{3}{ }^{-}=25: 75$ ratio had the highest values among the five treatments at red stage. However, we found that the content of vitamin $\mathrm{C}$, total phenols, and flavonoids were superior with T3 at mature green stage.

Pepper fruits were fractionated for the extraction of capsaicin and dihydrocapsaicin for the purpose of examining the influence of $\mathrm{NH}_{4}{ }^{+}: \mathrm{NO}_{3}{ }^{-}$ratio on the level of pungency. In mature green fruits, the contents of capsaicin (Figure 4A) and dihydrocapsaicin (Figure 4B) increased with increases in ammonium nitrogen and was highest at $\mathrm{NH}_{4}{ }^{+}: \mathrm{NO}_{3}{ }^{-}=25: 75$, and then decreased with further increase in ammonium nitrogen concentration. At mature green stage, the application of $\mathrm{NH}_{4}{ }^{+}: \mathrm{NO}_{3}{ }^{-}=25: 75$ (T3) increased the contents of capsaicin and dihydrocapsaicin by $25.1 \%$ and $79.3 \%$, respectively, more than T1. At red stage, the capsaicin in fruits produced with $\mathrm{NH}_{4}{ }^{+}: \mathrm{NO}_{3}{ }^{-}=25: 75$ (T3) had the highest content, which was $12.9 \%$ more than fruits from $\mathrm{T} 1$.

The effect of $\mathrm{NH}_{4}{ }^{+}: \mathrm{NO}_{3}{ }^{-}$ratio on the Scoville heat units (SHU) was evaluated using the values of capsaicin and dihydrocapsaicin (Figure 4C). Overall, SHU was significantly $(p<0.05)$ increased from mature green to the red stage, but the rate of increase varied with the different $\mathrm{NH}_{4}{ }^{+}: \mathrm{NO}_{3}{ }^{-}$ratios. Fruits from the pepper plants treated with $\mathrm{NH}_{4}{ }^{+}: \mathrm{NO}_{3}{ }^{-}$of $25: 75$ (T3) had the highest SHU values at the three stages of measurements, whereas those from the other treatments increased the SHU sharply from mature green to ripening and then leveled off from ripening to the red stage. 
Table 6. Effects of $\mathrm{NH}_{4}{ }^{+}: \mathrm{NO}_{3}{ }^{-}$ratios on quality of pepper fruit at the three stages in response to different $\mathrm{NH}_{4}{ }^{+}: \mathrm{NO}_{3}{ }^{-}$ratios.

\begin{tabular}{|c|c|c|c|c|c|c|}
\hline Variables & Stages & T1 & $\mathrm{T} 2$ & T3 & $\mathbf{T} 4$ & T5 \\
\hline \multirow{3}{*}{ Nitrate $\left(\mathrm{mg} \mathrm{g}^{-1} \mathrm{FW}\right)$} & Mature green stage & $0.51 \pm 0.02 \mathrm{bcd}$ & $0.46 \pm 0.02 \mathrm{de}$ & $0.44 \pm 0.02 \mathrm{e}$ & $0.42 \pm 0.01 \mathrm{e}$ & $0.43 \pm 0.01 \mathrm{e}$ \\
\hline & Ripening stage & $0.57 \pm 0.02 \mathrm{ab}$ & $0.558 \pm 0.03 \mathrm{abc}$ & $0.48 \pm 0.02 \mathrm{de}$ & $0.43 \pm 0.03 \mathrm{e}$ & $0.45 \pm 0.01 \mathrm{e}$ \\
\hline & Red stage & $0.60 \pm 0.01 \mathrm{a}$ & $0.59 \pm 0.01 \mathrm{a}$ & $0.51 \pm 0.03 \mathrm{bcd}$ & $0.49 \pm 0.01$ cde & $0.45 \pm 0.01 \mathrm{de}$ \\
\hline \multirow{3}{*}{ Vitamin $C\left(\mathrm{mg} \mathrm{g}^{-1} \mathrm{FW}\right)$} & Mature green stage & $0.46 \pm 0.02$ ef & $0.55 \pm 0.02 \mathrm{ab}$ & $0.57 \pm 0.02 \mathrm{a}$ & $0.50 \pm 0.02 \mathrm{bcd}$ & $0.51 \pm 0.02 \mathrm{bcd}$ \\
\hline & Ripening stage & $0.43 \pm 0.01 \mathrm{fg}$ & $0.55 \pm 0.03$ bcde & $0.59 \pm 0.02 \mathrm{abc}$ & $0.53 \pm 0.01$ cde & $0.51 \pm 0.00 \mathrm{de}$ \\
\hline & Red stage & $0.41 \pm 0.01 \mathrm{fg}$ & $0.43 \pm 0.01 \mathrm{fg}$ & $0.51 \pm 0.02 \mathrm{de}$ & $0.40 \pm 0.02 \mathrm{fg}$ & $0.40 \pm 0.01 \mathrm{~g}$ \\
\hline \multirow{3}{*}{ Soluble sugar $\left(\mathrm{mg} \mathrm{g}^{-1} \mathrm{FW}\right)$} & Mature green stage & $23.40 \pm 0.25$ cde & $23.15 \pm 0.16 \mathrm{de}$ & $25.70 \pm 1.04 \mathrm{abc}$ & $22.11 \pm 0.33 \mathrm{e}$ & $22.21 \pm 1.03 \mathrm{e}$ \\
\hline & Ripening stage & $22.01 \pm 0.48 \mathrm{e}$ & $22.75 \pm 0.21 \mathrm{de}$ & $25.03 \pm 0.40 \mathrm{bcd}$ & $21.77 \pm 0.29 \mathrm{e}$ & $21.50 \pm 0.84 \mathrm{e}$ \\
\hline & Red stage & $24.01 \pm 0.69$ bcde & $26.09 \pm 0.22 \mathrm{ab}$ & $27.37 \pm 0.34 \mathrm{a}$ & $25.11 \pm 0.30 \mathrm{bcd}$ & $23.84 \pm 0.35$ bcde \\
\hline \multirow{3}{*}{ Soluble protein $\left(\mathrm{mg} \mathrm{g}^{-1} \mathrm{FW}\right)$} & Mature green stage & $1.01 \pm 0.04 c$ & $1.00 \pm 0.09 c$ & $1.13 \pm 0.02 c$ & $0.94 \pm 0.03 c$ & $0.93 \pm 0.01 c$ \\
\hline & Ripening stage & $1.09 \pm 0.04 \mathrm{c}$ & $1.10 \pm 0.06 \mathrm{c}$ & $1.33 \pm 0.10 \mathrm{bc}$ & $1.10 \pm 0.08 c$ & $1.03 \pm 0.09 c$ \\
\hline & Red stage & $1.23 \pm 0.09 b c$ & $1.55 \pm 0.08 \mathrm{ab}$ & $1.69 \pm 0.10 \mathrm{a}$ & $1.20 \pm 0.08 b c$ & $1.35 \pm 0.24 b c$ \\
\hline \multirow{3}{*}{ Total phenols ( $\left.\mathrm{mg} \mathrm{g}^{-1} \mathrm{FW}\right)$} & Mature green stage & $39.39 \pm 2.31 \mathrm{bcd}$ & $41.99 \pm 0.85 \mathrm{bc}$ & $53.67 \pm 3.67 \mathrm{a}$ & $43.16 \pm 0.84 \mathrm{~b}$ & $42.86 \pm 1.61 \mathrm{~b}$ \\
\hline & Ripening stage & $31.44 \pm 3.01 \mathrm{~d}$ & $35.96 \pm 2.09 \mathrm{bcd}$ & $41.34 \pm 0.42 b c$ & $36.36 \pm 1.09 \mathrm{bcd}$ & $34.83 \pm 1.11 \mathrm{bcd}$ \\
\hline & Red stage & $32.72 \pm 1.02 \mathrm{~cd}$ & $35.32 \pm 2.50 \mathrm{bcd}$ & $43.67 \pm 2.36 b$ & $36.48 \pm 2.62 \mathrm{bcd}$ & $36.19 \pm 1.74 \mathrm{bcd}$ \\
\hline \multirow{3}{*}{ Flavonoid $\left(\mathrm{mg} \mathrm{g}^{-1} \mathrm{FW}\right)$} & Mature green stage & $23.37 \pm 0.88 \mathrm{bc}$ & $27.92 \pm 0.28 \mathrm{a}$ & $27.57 \pm 0.69 a$ & $21.89 \pm 1.03 \mathrm{bcd}$ & $19.83 \pm 1.43 \mathrm{cde}$ \\
\hline & Ripening stage & $20.65 \pm 0.82$ cde & $24.92 \pm 0.61 \mathrm{ab}$ & $24.57 \pm 0.94 \mathrm{ab}$ & $21.27 \pm 0.49 \mathrm{bcd}$ & $18.16 \pm 0.88 \mathrm{de}$ \\
\hline & Red stage & $19.31 \pm 0.95$ cde & $21.58 \pm 0.27 \mathrm{bcd}$ & $23.23 \pm 0.99 b c$ & $19.94 \pm 1.23$ cde & $17.16 \pm 0.69 \mathrm{e}$ \\
\hline \multirow{3}{*}{ Dry weight (g fruit ${ }^{-1} \mathrm{DW}$ ) } & Mature green stage & $1.37 \pm 0.12 \mathrm{f}$ & $1.3 \pm 0.06 \mathrm{f}$ & $2.17 \pm 0.06 \mathrm{bcd}$ & $1.85 \pm 0.04 \mathrm{de}$ & $1.57 \pm 0.07$ ef \\
\hline & Ripening stage & $1.83 \pm 0.02 \mathrm{de}$ & $1.88 \pm 0.07 \mathrm{de}$ & $2.23 \pm 0.03 b c$ & $2.13 \pm 0.09 \mathrm{~cd}$ & $1.83 \pm 0.06 \mathrm{de}$ \\
\hline & Red stage & $2.03 \pm 0.03 \mathrm{~cd}$ & $2.43 \pm 0.15 b$ & $2.87 \pm 0.03 \mathrm{a}$ & $2.80 \pm 0.10 \mathrm{a}$ & $2.10 \pm 0.10 \mathrm{~cd}$ \\
\hline
\end{tabular}

Note: ammonium $\left(\mathrm{NH}_{4}{ }^{+}\right)$; nitrate $\left(\mathrm{NO}_{3}{ }^{-}\right)$; fresh weight $(\mathrm{FW})$; dry weight $(\mathrm{DW})$. Values are means $\pm \mathrm{SE}(n=3$ replicates with 12 fruits per replicate). Significant differences $(p<0.05)$ were

indicated by different letters for each variable. The treatment details were defined in Table 2 above. 


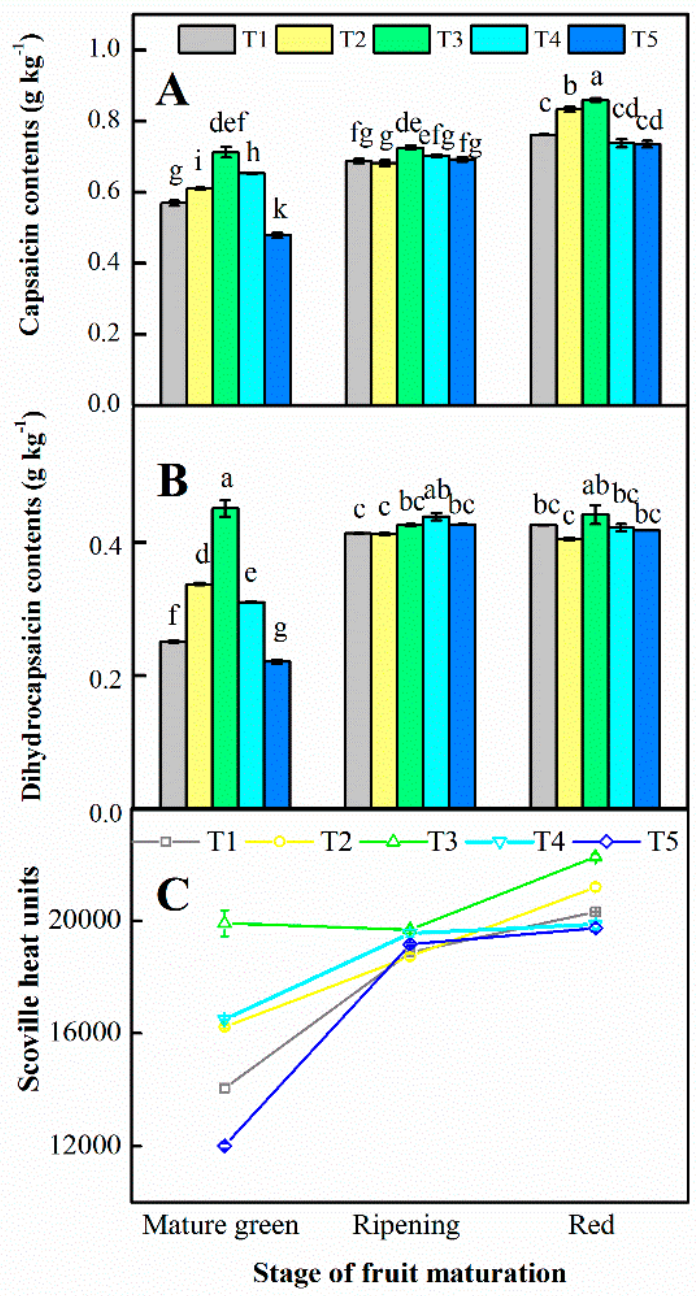

Figure 4. Capsaicin (A), dihydrocapsaicin (B) contents and Scoville heat units (C) in pepper fruit at the mature green, ripening, and red stage in response to different $\mathrm{NH}_{4}{ }^{+}: \mathrm{NO}_{3}{ }^{-}$ratios. Vertical bars represent mean \pm SE ( $n=3$, each replicate consisted of 12 pepper fruits) and the different letters denote significant differences $(p<0.05)$. The five treatments were defined in Figure 1 above.

\subsection{Activity of Enzyme and Gene Expression of Nitrogen Metabolism}

To determine the effects of $\mathrm{NH}_{4}{ }^{+}: \mathrm{NO}_{3}{ }^{-}$ratio on nitrogen metabolism in pepper plants, we measured the activities of NR (Figure 5A), NiR (Figure 5B), GS (Figure 5C), and GOGAT (Figure 5D) at $30,60,90$, and 120 DAT. We found that activities of these enzymes varied largely among treatments $(p<0.05)$ and among the different times $(p<0.05)$ of measurement. At 30 and 60 DAT, the NR activity decreased significantly as the proportion of nitrate in the $\mathrm{NH}_{4}{ }^{+}: \mathrm{NO}_{3}{ }^{-}$ratio was decreased (Figure 5A). However, at $90 \mathrm{DAT}$, plants treated with $\mathrm{NH}_{4}{ }^{+}: \mathrm{NO}_{3}{ }^{-}$ratio of $25: 75$ (T3) had the highest NR activity. The effect of the treatments on NiR activity was similar to what was observed in the NR activity (Figure 5B). Among the five ratio treatments and four times evaluated, the highest NiR activity obtained with the T1 treatment was $5.72 \mu \mathrm{mol} \mathrm{h}^{-1} \mathrm{~g}^{-1}$ at 60 DAT.

Different ammonium and nitrate ratios had a significant effect $(p<0.05)$ on GS activity (Figure 5C), and the activity increased with the increased proportion of ammonium in the $\mathrm{NH}_{4}{ }^{+}: \mathrm{NO}_{3}{ }^{-}$ratio, then leveled off or declined. At the various times of data measurement, $\mathrm{T} 3\left(\mathrm{NH}_{4}{ }^{+}: \mathrm{NO}_{3}{ }^{-}=25: 75\right)$ and T4 $\left(\mathrm{NH}_{4}{ }^{+}: \mathrm{NO}_{3}{ }^{-}=37.5: 62.5\right)$ had highest GS activities at Day 90, averaging 215.2 and $233.4 \mu \mathrm{mol} \mathrm{h}^{-1} \mathrm{~g}^{-1}$, respectively. In comparison, the response of GOGAT activity to the treatments were significantly interacted with the days of transplantation $(p<0.05)$; at Day 30, the highest GOGAT activity was 
attained with the T4 treatment, whereas at Day 90 and 120, the highest GOGAT activity was with T3 treatment, and at Day 60, T3 and T4 both achieved the highest GOGAT activities (Figure 5D).

Using qRT-PCR, we measured the relative expression levels of 7 genes involved in nitrogen metabolic pathway associated with the different $\mathrm{NH}_{4}{ }^{+}$and $\mathrm{NO}_{3}{ }^{-}$ratios in 60-d old pepper leaves. Figure $6 \mathrm{~A}, \mathrm{~B}$ manifested the expression levels of 2 genes $(N R-1, N R-2)$ related to nitrate reduction were up-regulated with 12.5 to $37.5 \%$ of $\mathrm{NH}_{4}{ }^{+}-\mathrm{N}$ in the $\mathrm{NH}_{4}{ }^{+}-\mathrm{NO}_{3}{ }^{-}$ratio. Compared to $\mathrm{T} 1$ which had $100 \%$ nitrate in the $\mathrm{NH}_{4}{ }^{+}-\mathrm{NO}_{3}{ }^{-}$ratio, all the other treatments showed an up-regulated expression of $\mathrm{NiR}$ (Figure 6C) in nitrite reduction, with the $\mathrm{NH}_{4}{ }^{+}: \mathrm{NO}_{3}{ }^{-}$ratio of 12.5:87.5 (T2) and 25:75 (T3) being the highest. Figure $6 \mathrm{D}$ and $6 \mathrm{E}$ also showed that the relative expression of GS-1 and GS-2 were up-regulated when the plants were treated with $12.5 \%$ to $37.5 \%$ of $\mathrm{NH}_{4}{ }^{+}-\mathrm{N}$, but there was no significant difference among T2, T3, and T4. The expression levels of GOGAT-1 (Figure 6F) and GOGAT-2 (Figure 6G) in plants treated with $\mathrm{NH}_{4}{ }^{+}: \mathrm{NO}_{3}{ }^{-}=25: 75$ (T3) were 8.5 and 4.7-fold, respectively, more than T1.

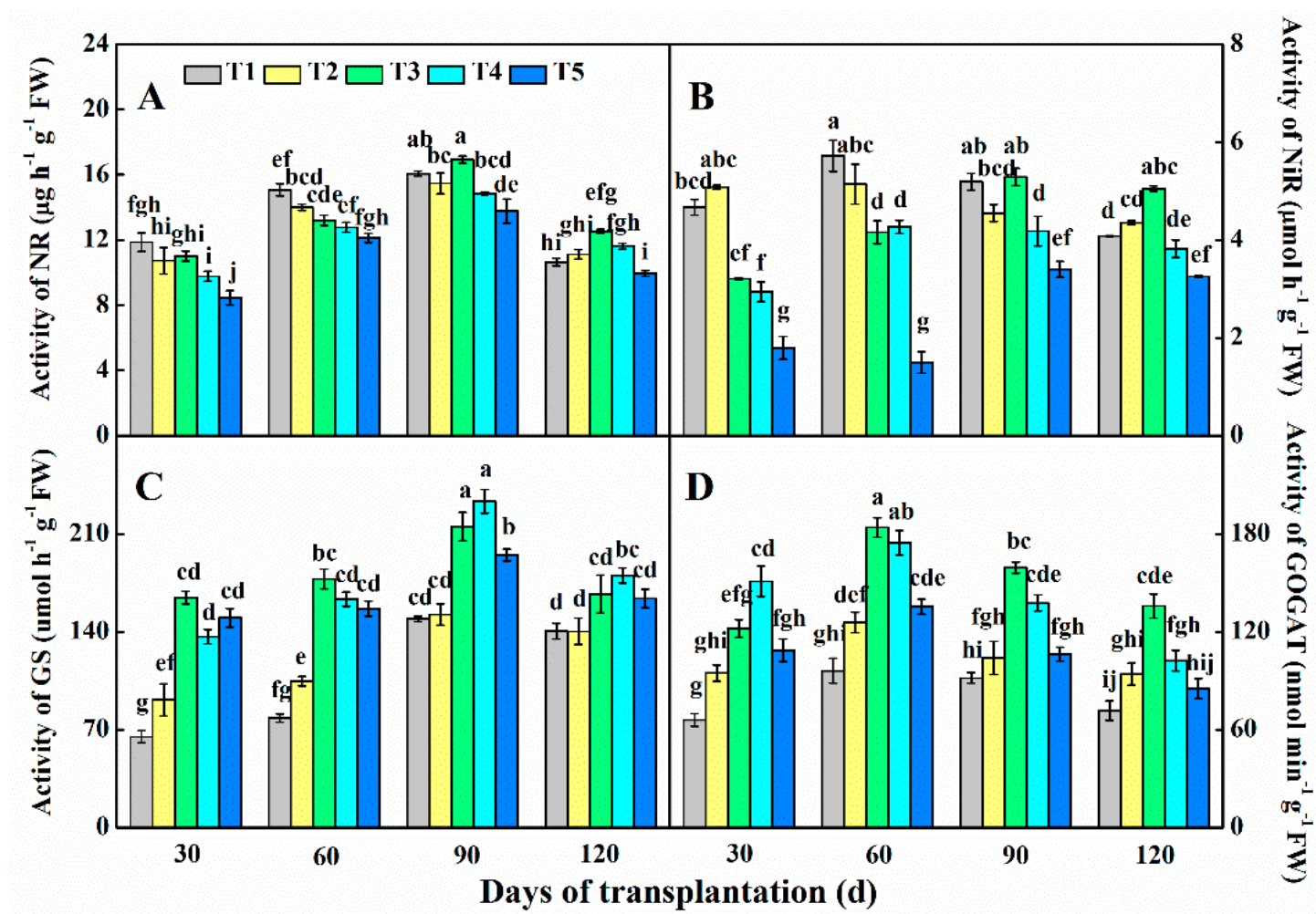

Figure 5. Activities of NR (A), NiR (B), GS (C), and GOGAT (D) enzymes in pepper leaves at the different $\mathrm{NH}_{4}{ }^{+}: \mathrm{NO}_{3}{ }^{-}$ratios. Vertical bars represent mean $\pm \mathrm{SE}$ from three independent replicates and the different letters denote significant differences $(p<0.05)$. The five treatments were defined in Figure 1 above. Abbreviations: nitrate reductase (NR); nitrite reductase (NiR); Glutamine synthetase (GS); glutamate synthases (GOGAT). 

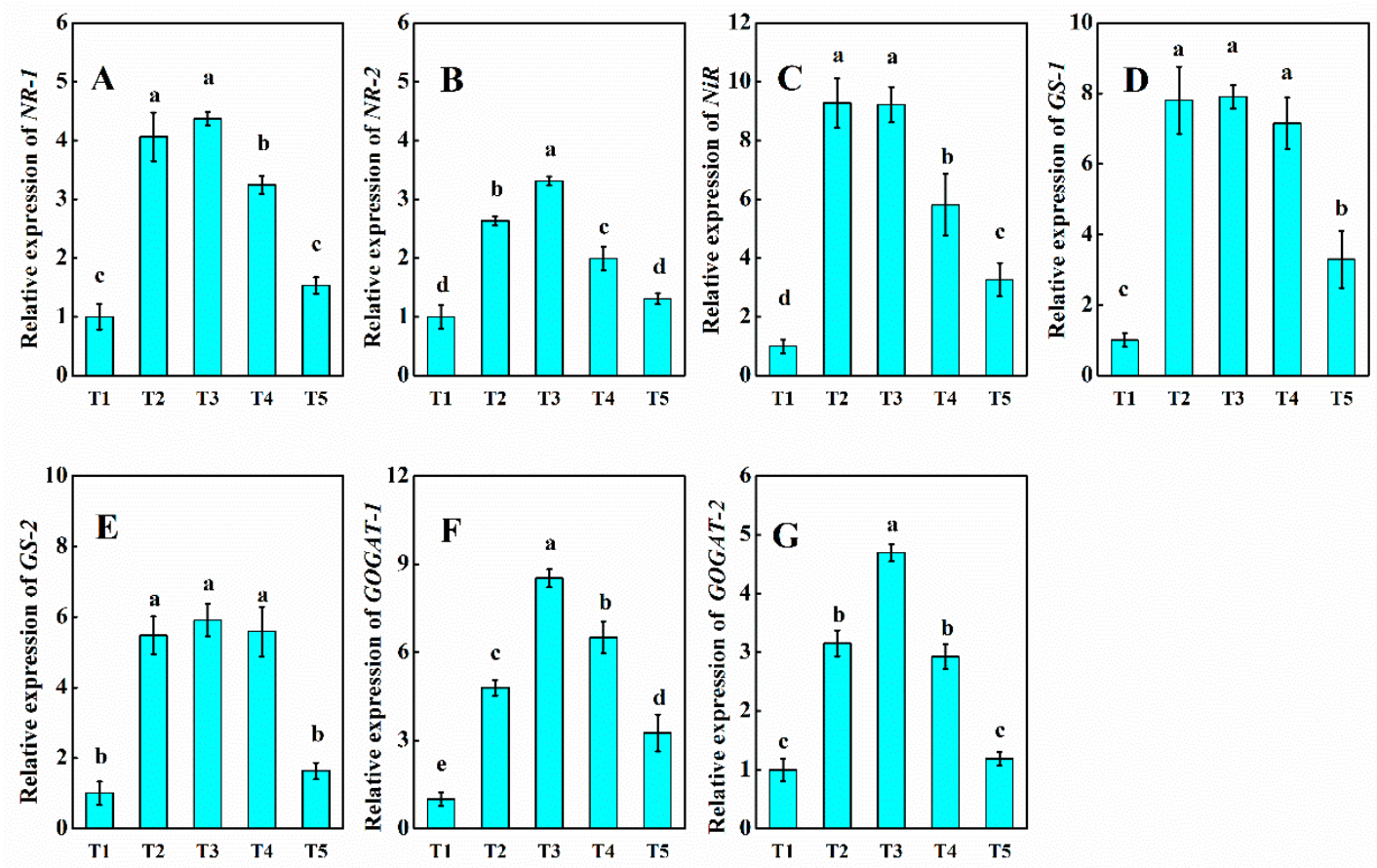

Figure 6. The relative expression of NR-1 (A), NR-2 (B), NiR (C), GS-1 (D), GS-2 (E), GOGAT-1 (F), and GOGAT-2 (G) genes involved in nitrogen metabolism in pepper leaves 60 days after transplantation at the five different $\mathrm{NH}_{4}{ }^{+}: \mathrm{NO}_{3}{ }^{-}$ratios (T1, T2, . T5). Vertical bars represent mean $\pm \mathrm{SE}$ from three independent replicates and the different letters denote significant differences $(p<0.05)$ among treatments. Abbreviations: nitrate reductase (NR); nitrite reductase (NiR); Glutamine synthetase (GS); glutamate synthases (GOGAT).

\section{Discussion}

\subsection{Ammonium-Nitrate Ratios and Plant Growth, N, P, and K Accumulation and Distribution}

Maximizing the dry matter accumulation is essential to fruit yield in pepper. In the present study, we found that the supply of the appropriate ratio of the two main nitrogen forms induced a synergistic growth response that surpassed the maximum growth rate produced by sole application of $\mathrm{NO}_{3}{ }^{-}-\mathrm{N}$. Our results demonstrate that appropriate $\mathrm{NH}_{4}{ }^{+}: \mathrm{NO}_{3}{ }^{-}$ratio in nitrogen application is an effective way to promote the accumulation of photosynthetic materials in the vegetative tissues of peppers. However, plants were treated with ratio of $\mathrm{NH}_{4}{ }^{+}: \mathrm{NO}_{3}{ }^{-}$50:50 shown the decreased promoting effect, which indicated that high concentration of ammonium nitrogen could inhibit the growth of pepper plants. Such a phenomenon has also been reported in other species, such as ryegrass (Lolium multiflorum ssp.) [51]. Furthermore, we found that an appropriate ammonium-nitrate ratio stimulated root development in pepper including root length, surface areas, volume, and root tips. Root growth is influenced by the nitrogen forms available in the surrounding media, and plants may develop longer roots when ammonium is the primary nitrogen source [52]. Root nitrogen acquisition alters the rhizosphere $\mathrm{pH}$ and redox potential, which in turn regulates root cell proliferation and the mechanical properties. Usually, the root regeneration capacity of pepper is inferior, and the main roots are typically distributed in the $0-25 \mathrm{~cm}$ of the top soil [53]. In our study, the addition of appropriate amount of ammonium nitrogen was beneficial to the pepper root architecture, especially with the application of $\mathrm{NH}_{4}{ }^{+}: \mathrm{NO}_{3}{ }^{-}$at the 25:75 and 37.5:62.5 ratios. These treatments led to higher root surface area and longer roots that allowed the accumulation of more mineral nutrients.

The accumulation of $\mathrm{N}, \mathrm{P}$, and $\mathrm{K}$ in plants is closely related to the growth and development processes. Nitrogen plays a key role in the formation of cells, tissues, and organs. Phosphorus participates in the balance and regulation of acid and alkali, the metabolism of energy, and the 
maintenance of the metabolism of ATP balance. Potassium promotes the synthesis and transportation of amino acids, proteins, and carbohydrates in plants, and K cycling acts as an important signal for feedback regulation of nutrient uptake [54,55]. In the present study, we found that pepper plants supplied with $25 \%$ ammonium and $75 \%$ nitrate had the highest contents of N, P, and K accumulated in the different organs (leaves, stems, roots, fruits), suggesting that this ratio has a potential interest in fertilization for improving $\mathrm{N}, \mathrm{P}, \mathrm{K}$ use efficiency. However, as compared to 0:100 of $\mathrm{NH}_{4}{ }^{+}: \mathrm{NO}_{3}{ }^{-}$, total plant N content and NUE of sorghum (Sorghum bicolor L. Moench) were reduced by mixed $\mathrm{N}$ source [56]. When watermelon (Citrullus lanatus) plants were supplied with mixed $\mathrm{NO}_{3}{ }^{-}$and $\mathrm{NH}_{4}{ }^{+}$, higher concentrations of $\mathrm{N}$ and $\mathrm{P}$ were observed [57]. Tu et al. suggested that the increased availability of $\mathrm{P}$ was mainly due to the effect of the $\mathrm{NH}_{4}{ }^{+}$source on the $\mathrm{pH}$ of the rhizosphere soil [15]. Shaviv A et al. found that when the ratio of ammonium to nitrate was increased, $\mathrm{K}$ addition to soil increased the utilization of $\mathrm{N}$ fertilizers, demonstrating the existence of a positive effect of the $\mathrm{N}-\mathrm{K}$ interaction in wheat [58]. However, in Dieffenbachia amoena the form of supplied $\mathrm{N}\left(\mathrm{NH}_{4}{ }^{+}-\mathrm{N}\right.$ or $\mathrm{NO}_{3}{ }^{-}-\mathrm{N}$ ) does not affect the $\mathrm{K}$ uptake [59].

Compared with the sole nitrate treatment $\left(\mathrm{NH}_{4}{ }^{+}: \mathrm{NO}_{3}{ }^{-}=0: 100\right)$, the addition of ammonium affected the distribution of $\mathrm{N}, \mathrm{P}$, and $\mathrm{K}$ in plant tissues; $\mathrm{NH}_{4}{ }^{+}: \mathrm{NO}_{3}{ }^{-}$ratio at 50:50 increased $\mathrm{N}, \mathrm{P}$, and $\mathrm{K}$ concentrations in roots and decreased those in leaves. The assimilation of ammonium in the pepper root promoted the higher root $\mathrm{N}$ content, whereas the assimilation of nitrate mainly occurred in the shoot; hence, more $\mathrm{N}$ was detected in leaves when $\mathrm{NH}_{4}{ }^{+}: \mathrm{NO}_{3}{ }^{-}$was applied at the ratio of 0:100. It has been reported that appropriate ammonium-nitrate ratio in nitrogen fertilization is essential to balance $\mathrm{NH}_{4}{ }^{+}$and $\mathrm{NO}_{3}{ }^{-}$in the assimilation of nitrogen in higher plants [60].

\subsection{Ammonium-Nitrate Ratios and the Quality and Capsaicinoids}

Higher nitrate concentration in pepper fruits is not ideal for consumers. In this study, we anticipated that the nitrate concentration in pepper fruits could be regulated through the controlling of nitrate uptake during the reproductive growth period. Nitrate availability to the plants through the application of ammonium versus nitrate fertilization could regulate the outcome. We found that when the $\mathrm{NH}_{4}{ }^{+}: \mathrm{NO}_{3}{ }^{-}$ratio in nitrogen application was at 25:75 (i.e., the T3 treatment), the fruits nitrate content decreased significantly $(p<0.05)$ compared with sole nitrate application (i.e., $\left.\mathrm{NH}_{4}{ }^{+}: \mathrm{NO}_{3}{ }^{-}=0: 100\right)$. Also, fruit at the red stage had higher content than mature green and ripening stage. Nevertheless, according to Kołton et al., nitrate ion accumulation was higher in green pepper fruits when supplied with mixed nitrogen fertilization [33]. The application of $\mathrm{NH}_{4}{ }^{+}: \mathrm{NO}_{3}{ }^{-}$ratio (25:75) increased the contents of vitamin C, soluble sugars, soluble proteins, total phenols, flavonoids and dry matter in the fruits compared to the sole nitrate fertilization. In addition, the improvement of fruit length, width, weight, and number of fruits per plant, leading to the enhancement of the appearance quality (Supplementary Materials). Our findings added new values to the scientific literature that some of the key quality-related variables will be affected by the ammonium-nitrate fertilization ratio, but not all of them like the size of fruits in apple [61].

The soluble sugars content in pepper fruits increased in plants with T3; this was probably due to improvement in the absorption of $\mathrm{K}$. It was demonstrated that $\mathrm{K}$ fertilization increases the sugar accumulation in soybean seeds [62]. Zhang et al. showed that $\mathrm{K}$ fertilization increased soluble sugar content of apple fruit (Malus domestica Borkh. Cv. Fuji) by regulating trehalose metabolism [63]. Moreover, $\mathrm{Xu} \mathrm{G}$, et al. reported that the $\mathrm{N}$ and $\mathrm{K}$ nutrition status of pepper have effects on the components of both inorganic and organic solutes of seeds [64]. Higher soluble protein in the pepper fruits from T3 were related to increased nitrogen metabolism under the specific ammonium-nitrate ratio, as protein $\mathrm{N}$ accounts for 80 to $85 \%$ of the total $\mathrm{N}$ accumulated in green material. The highest nitrate content in the organs of plants with the sole nitrate treatment suggests the imbalance between the supply and demand of nitrogen nutrient needed for an optimal growth. Therefore, the use of nitrate as sole nitrogen source in pepper production is not an ideal practice and even unacceptable 
in food nutrition. Thus, an effective strategy to reduce nitrate content in peppers is to control nitrate availability by replacing the nitrate with ammonium in an appropriate ratio.

Capsaicinoids are important indicators of the quality of pepper fruits. In several studies, the synthesis of capsaicinoid was greatly influenced by environmental conditions. Gurung et al. showed there were significant differences in capsaicinoid content among different cultivars and different cultivation environments [65]. Pungency in pepper varies greatly with soil type particularly depending on soil organic $C$ content, microbial activity and nutrient content [66]. In our study, the contents of capsaicin and dihydrocapsaicin were significantly higher with the application of ammonium-nitrate ratio at 25:75 compared to the other treatments. It has been reported that the precursors of capsaicinoid compounds have two biosynthesis pathways: phenylpropane pathway by using phenylalanine as precursor and branched fatty acid pathway with valine as precursors [67]. Research of Mazourek comprehensively analyzed the anabolism network of capsaicin substances, phenylalanine ammonia-lyase (PAL), GOGAT, and GS were regarded as candidate enzymes in Capsaicinoid biosynthetic pathway [68]. The GOGAT and GS enzymes were affected by appropriate ammonium supply in this study, which may associate with the enhanced synthesis of capsaicinoids in pepper fruits. Flavonoids and phenols are secondary metabolites widely found in plants, their synthesis is regulated by the common speed-limiting enzyme PAL. However, it is not clear whether PAL was affected by nitrogen metabolism, the mechanisms responsible for the improved capsaicinoids, flavonoids and phenols in peppers need to be further investigated.

\subsection{Ammonium-Nitrate Ratios and Nitrogen Metabolism Gene Expression}

In higher plants, nitrate reductase (NR) is a complex enzyme containing two identical subunits, which exists as a dimer. $\mathrm{NO}_{3}{ }^{-}$must be converted into $\mathrm{NO}_{2}{ }^{-}$and then reduced to $\mathrm{NH}_{4}{ }^{+}$by nitrite reductase (NiR) in energy-requiring reactions before being assimilated into amino acids. It has been established that NR and NiR activity in higher plants is typically dependent on nitrate availability, such as on ryegrass [69], Salvinia natans [70], Canna indica [71], and Nicotiana plumbaginifolia [72]. Our data indicate that $\mathrm{NR}$ and NiR activities decreased with the increased proportion of ammonium in the $\mathrm{NH}_{4}{ }^{+}: \mathrm{NO}_{3}{ }^{-}$ratio at 30, 60, and $90 \mathrm{DAT}$, but during the later growth stage (120 DAT), the application of $\mathrm{NH}_{4}{ }^{+}: \mathrm{NO}_{3}{ }^{-}=25: 75$ led to higher NR and NiR activities than the other treatments. Glutamine synthetase (GS), one of the key enzymes in ammonia assimilation, can catalyze the synthesis of glutamine from ammonium and glutamic acid, which apart from preventing excess ammonium ions from poisoning organisms, also serves as the main storage and transportation form of ammonium [73,74]. Plants contain two glutamate synthases; one receiving electrons from ferrodoxin (GOGAT-1) and the other receiving electrons from NADH (GOGAT-2), thus, the increase of glutamine level stimulates the activity of glutamate synthase to produce glutamate. MosheSagi et al. suggested that the N source had no significant effect on GS activity [69]. In another study, the increased activity of GS was found in the embryogenic tissue of pumpkin (Cucurbita pepo L.) when the $\mathrm{NH}_{4}{ }^{+}$was the sole source of nitrogen [75]. In the present study, the highest GS and GOGAT enzyme activity were observed when the ratio of ammonium to nitrate was either $25: 75$ or 37.5:62.5. However, an optimal ammonium-nitrate ratio may depend on other factors, such as temperature [29], atmospheric $\mathrm{CO}_{2}$ concentration [76] and soil microorganisms [77].

The relative expression of seven key genes involved in nitrogen metabolism was analyzed. The results showed that the expression levels of the genes were up-regulated in pepper plants which were fertilized with the different ammonium-nitrate ratios compared with those under sole nitrate treatment. Our results indicate that the two nitrogen sources may work together to induce up-regulated expression of nitrogen metabolism-related genes that regulated the activity of corresponding enzymes. Finally, leading to improve nitrogen uptake in plant tissues and interfere with carbohydrate compounds accumulation of fruits [78]. However, there was no obvious linkage between NR and NiR enzyme activity and gene expression in peppers under the different $\mathrm{NH}_{4}{ }^{+}: \mathrm{NO}_{3}{ }^{-}$ratio treatments. It is reported that the profound changes of nitrogen metabolite levels were resulted by the additional deregulation 
at the posttranslational level [79]. In romaine lettuce (Lactuca sativa L.), it was found that the transcript abundance was poorly linked to de novo protein synthesis due to profound regulation at the level of translation [80]. In our study, adding $\mathrm{NH}_{4}{ }^{+}-\mathrm{N}$ influenced GS/GOGAT expression, but when $\mathrm{NH}_{4}{ }^{+}: \mathrm{NO}_{3}{ }^{-}=50: 50$ was applied, the expression levels of NR, GS-2, GOGAT-2 were not up-regulated, suggesting that excessive ammonium ions are toxic in pepper and $\mathrm{NH}_{4}{ }^{+}$uptake and metabolism may be tightly regulated. Compared with the single nitrate nitrogen, the addition of moderate $\mathrm{NH}_{4}{ }^{+}$was beneficial for enhancing the genes expression of GS, GOGAT and activating GS/GOGAT enzymes. Hence, the stimulation of nitrogen metabolism contributed to promote growth of shoot, root, and the pungency of fruit.

\section{Conclusions}

In conclusion, our study has shown that different $\mathrm{NH}_{4}{ }^{+}: \mathrm{NO}_{3}{ }^{-}$ratio affects the growth, nutrient element accumulation and quality of fruits differently in pepper plants. The results have demonstrated that $\mathrm{NH}_{4}{ }^{+}: \mathrm{NO}_{3}{ }^{-}$(25:75) is the most suitable ratio, as it improved root growth and accumulation of nutrient elements ( $\mathrm{N}, \mathrm{P}$ and $\mathrm{K}$ ) and subsequently increased dry matter accumulation in the pepper plants. Moreover, the application of $\mathrm{NH}_{4}{ }^{+}: \mathrm{NO}_{3}{ }^{-}$(25:75) enhanced fruit quality by increasing the contents of vitamin $\mathrm{C}$, soluble sugar, soluble protein, total phenols, flavonoids, dry matter, and pungency of the fruits. It can be concluded that $\mathrm{NH}_{4}{ }^{+}: \mathrm{NO}_{3}{ }^{-}(25: 75)$ is the most appropriate ratio to promote plant growth, root development and fruit quality in pepper production, and this is probably linked to the observed induction in GS and GOGAT expression and enzymes activities, in nitrogen metabolism.

Supplementary Materials: The following are available online at http://www.mdpi.com/2073-4395/9/11/683/s1, Table S1: Dry matter of the shoot, root and dry matter accumulation rate of pepper plants at different days after transplantation, Table S2: Effects of $\mathrm{NH}^{+}: \mathrm{NO}^{-}$ratios on root morphological parameters of pepper at different days after transplantation, Table S3: Total N, P, and K accumulation in the pepper plants at different days after transplantation, Table S4: The nitrate, vitamin C, soluble sugar, soluble protein, total phenols, flavonoids contents and dry matter of pepper fruit at mature green, ripening and red stage, Table S5: Effects of $\mathrm{NH}_{4}^{+}: \mathrm{NO}^{-}$ratios on fruit length, fruit width, weight of fresh fruit, and fruit number per plant, Table S6: Capsaicin, dihydrocapsaicin contents and Scoville heat units in pepper fruit at the mature green, ripening, and red stage, Table S7: Activities of NR (A), NiR (B), GS (C), and GOGAT (D) enzymes in pepper leaves at different days after transplantation.

Author Contributions: Conceptualization, J.Z. and J.L. (Jian Lv); Data curation, J.L. (Jing Li) and X.Z.; Formal analysis, J.Z. and J.L. (Jian Lv); Funding acquisition, J.X.; Methodology, J.Z., C.T. and C.W.; Resources, J.Y.; Supervision, J.X.; Writing—original draft, J.Z.; Writing—review \& editing, M.M.D. and Y.G.

Funding: This research was funded by the National Key Research and Development Program of China [2016YFD0201005].

Conflicts of Interest: The authors declare no conflict of interest.

\section{References}

1. Li, H.; Wang, L.; Li, J.; Gao, M.; Zhang, J.; Zhang, J.; Qiu, J.; Deng, J.; Li, C.; Frolking, S. The development of China-DNDC and review of its applications for sustaining Chinese agriculture. Ecol. Model. 2017, 348, 1-13. [CrossRef]

2. Lu, W.; Zhang, H.; Min, J.; Shi, W. Dissimilatory nitrate reduction to ammonium in a soil under greenhouse vegetable cultivation as affected by organic amendments. J. Soils Sediment. 2015, 15, 1169-1177. [CrossRef]

3. Kalcsits, L.A.; Guy, R.D. Variation in fluxes estimated from nitrogen isotope discrimination corresponds with independent measures of nitrogen flux in Populus balsamifera L. Plant Cell Environ. 2016, 39, 310-319. [CrossRef] [PubMed]

4. Lassaletta, L.; Billen, G.; Grizzetti, B.; Anglade, J.; Garnier, J. 50 year trends in nitrogen use efficiency of world cropping systems: The relationship between yield and nitrogen input to cropland. Environ. Res. Lett. 2014, 9, 105011. [CrossRef]

5. Carlisle, E.; Myers, S.; Raboy, V.; Bloom, A. The effects of inorganic nitrogen form and $\mathrm{CO}_{2}$ concentration on wheat yield and nutrient accumulation and distribution. Front. Plant Sci. 2012, 3, 195. [CrossRef] [PubMed]

6. Haynes, R.J.; Goh, K.M. Ammonium and nitrate nutrition of plants. Biol. Rev. 2010, 53, 465-510. [CrossRef] 
7. Piwpuan, N.; Zhai, X.; Brix, H. Nitrogen nutrition of Cyperus laevigatus and Phormium tenax: Effects of ammonium versus nitrate on growth, nitrate reductase activity and $N$ uptake kinetics. Aquat. Bot. 2013, 106, 42-51. [CrossRef]

8. Miller, A.J.; Cramer, M.D. Root nitrogen acquisition and assimilation. Plant Soil 2005, 274, 1-36. [CrossRef]

9. Fernandez, E.; Galvan, A. Inorganic nitrogen assimilation in Chlamydomonas. J. Exp. Bot. 2007, 58, $2279-2287$. [CrossRef]

10. Martínez-Andújar, C.; Ghanem, M.E.; Albacete, A.; Pérez-Alfocea, F. Response to nitrate/ammonium nutrition of tomato (Solanum lycopersicum L.) plants overexpressing a prokaryotic $\mathrm{NH}_{4}{ }^{+}$-Dependent asparagine synthetase. J. Plant Physiol. 2013, 170, 676-687.

11. Bock, B.R. Increasing cereal yields with higher ammonium/nitrate ratios: Review of potentials and limitations. Environ. Lett. 1986, 21, 723-758. [CrossRef]

12. Urlić, B.; Špika, M.J.; Becker, C.; Kläring, H.P.; Krumbein, A.; Ban, S.G.; Schwarz, D. Effect of $\mathrm{NO}_{3}$ and $\mathrm{NH}_{4}$ concentrations in nutrient solution on yield and nitrate concentration in seasonally grown leaf lettuce. Acta Agric. Scand. Sect. B Soil Plant Sci. 2017, 67, 748-757.

13. Tabatabaei, S.J.; Fatemi, L.S.; Fallahi, E. Effect of ammonium: nitrate ratio on yield, calcium concentration, and photosynthesis rate in strawberry. J. Plant Nutr. 2006, 29, 1273-1285. [CrossRef]

14. Chanceiii, W.; Somda, Z.; Mills, H. Effect of nitrogen form during the flowering period on zucchini squash growth and nutrient element uptake. J. Plant Nutr. 1999, 22, 597-607. [CrossRef]

15. Ruan, J.L.; Sattelmacher, B. Effect of nitrogen form and root-zone $\mathrm{pH}$ on growth and nitrogen uptake of tea (Camellia sinensis) plants. Ann. Bot. 2007, 99, 301-310. [CrossRef]

16. Boczulak, S.A.; Hawkins, B.J.; Roy, R. Temperature effects on nitrogen form uptake by seedling roots of three contrasting conifers. Tree Physiol. 2014, 34, 513-523. [CrossRef]

17. Wada, S.; Niedz, R.P.; Reed, B.M. Determining nitrate and ammonium requirements for optimal in vitro response of diverse pear species. In Vitro Cell. Dev. Biol. Plant 2015, 51, 19-27. [CrossRef]

18. Tromp, J.; Ovaa, J.C. Uptake and distribution of nitrogen in young apple trees after application of nitrate or ammonium, with special reference to asparagine and arginine. Physiol. Plant 2010, 45, 23-28. [CrossRef]

19. Babalar, M.; Sokri, S.M.; Lesani, H.; Asgari, M.A.; Barker, A.V. Effects of nitrate:ammonium ratios on vegetative growth and mineral element composition in leaves of apple. J. Plant Nutr. 2015, 38, 2247-2258. [CrossRef]

20. Borrero, C.; Trillas, M.I.; Delgado, A.; Avilés, M. Effect of ammonium/nitrate ratio in nutrient solution on control of Fusarium wilt of tomato by Trichoderma asperellum T34. Plant Pathol. 2012, 61, 132-139. [CrossRef]

21. Horchani, F.; Hajri, R.; Aschismiti, S. Effect of ammonium or nitrate nutrition on photosynthesis, growth, and nitrogen assimilation in tomato plants. J. Plant Nutr. Soil Sci. 2010, 173, 610-617. [CrossRef]

22. Kronzucker, H.J.; Glass, A.D.M.; Siddiqi, M.Y.; Kirk, G.J.D. Comparative kinetic analysis of ammonium and nitrate acquisition by tropical lowland rice: implications for rice cultivation and yield potential. New Phytol. 2010, 145, 471-476. [CrossRef]

23. Guo, S.; Gui, C.; Yi, Z.; Shen, Q. Ammonium nutrition increases photosynthesis rate under water stress at early development stage of rice (Oryza sativa L.). Plant Soil 2007, 296, 115-124. [CrossRef]

24. Zhang, Y.; Lv, H.; Wang, D.; Deng, J.; Song, W.; Makeen, K.; Shen, Q.; Xu, G. Partial nitrate nutrition amends photosynthetic characteristics in rice (Oryza sativa L. var. japonica) differing in nitrogen use efficiency. Plant Growth Regul. 2011, 63, 235-242. [CrossRef]

25. Helali, S.M.R.; Nebli, H.; Kaddour, R.; Mahmoudi, H.; Lachaâl, M.; Ouerghi, Z. Influence of nitrate-Ammonium ratio on growth and nutrition of Arabidopsis thaliana. Plant Soil 2010, 336, 65-74. [CrossRef]

26. Masakapalli, S.K.; Kruger, N.J.; Ratcliffe, R.G. The metabolic flux phenotype of heterotrophic Arabidopsis cells reveals a complex response to changes in nitrogen supply. Plant J. 2013, 74, 569-582. [CrossRef]

27. Marino, D.; Ariz, I.; Lasa, B.; Santamaría, E.; Fernández-Irigoyen, J.; González-Murua, C.; Aparicio Tejo, P.M. Quantitative proteomics reveals the importance of nitrogen source to control glucosinolate metabolism in Arabidopsis thaliana and Brassica oleracea. J. Exp. Bot. 2016, 67, 3313-3323. [CrossRef]

28. Hu, L.; Yu, J.; Liao, W.; Zhang, G.; Xie, J.; Lv, J.; Xiao, X.; Yang, B.; Zhou, R.; Bu, R. Moderate ammonium:nitrate alleviates low light intensity stress in mini Chinese cabbage seedling by regulating root architecture and photosynthesis. Sci. Hortic. 2015, 186, 143-153. [CrossRef] 
29. Liu, G.; Du, Q.; Li, J. Interactive effects of nitrate-ammonium ratios and temperatures on growth, photosynthesis, and nitrogen metabolism of tomato seedlings. Sci. Hortic. 2017, 214, 41-50. [CrossRef]

30. Maksimova, V.; Gudeva, L.K.; Gulaboski, R.; Nieber, K. Co-extracted bioactive compounds in Capsicum fruit extracts prevents the cytotoxic effects of capsaicin on B104 neuroblastoma cells. Revista Brasileira Farmacognosia 2016, 26, 744-750. [CrossRef]

31. Robbins, W. Clinical applications of capsaicinoids. Clin. J. Pain 2000, 16, 86-89. [CrossRef]

32. Marti, H.; Mills, H. Nutrient uptake and yield of sweet pepper as affected by stage of development and N form. J. Plant Nutr. 1991, 14, 1165-1175. [CrossRef]

33. Kołton, A.; Wojciechowska, R.; Leja, M. The effect of various light conditions and different nitrogen forms on nitrogen metabolism in pepper fruits. Folia Hortic. 2012, 24, 153-160. [CrossRef]

34. Hoagland, D.R.; Arnon, D.I. The water-culture method for growing plants without soil. Calif. Agric. Exp. Stn. Circ. 1950, 347, 357-359.

35. Cruz, J.L.; Alves, A.A.C.; Lecain, D.R.; Ellis, D.D.; Morgan, J.A. Effect of elevated $\mathrm{CO}_{2}$ concentration and nitrate: Ammonium ratios on gas exchange and growth of cassava (Manihot esculenta Crantz). Plant Soil 2014, 374, 33-43. [CrossRef]

36. Hu, L.; Liao, W.; Dawuda, M.M.; Yu, J.; Lv, J. Appropriate $\mathrm{NH}_{4}{ }^{+}: \mathrm{NO}_{3}{ }^{-}$ratio improves low light tolerance of mini Chinese cabbage seedlings. BMC Plant Biol. 2017, 17, 22. [CrossRef] [PubMed]

37. Galliher, T.L. Comparison of Dumas and Kjeldahl methods with automatic analyzers on agricultural samples under routine rapid analysis conditions. Commun. Soil Sci. Plant Anal. 2001, 32, 2007-2019.

38. Konieczynski, P.; Wesolowski, M. Total phosphorus and its extractable form in plant drugs. Interrelation with selected micro- and macroelements. Food Chem. 2007, 103, 210-216. [CrossRef]

39. Neaă, G.; Hoza, G.; Teodorescu, R.I.; Basarabă, A.; Petcuci, A.; Sima, R. Phosphorus, potassium and nitrate contents in fruit of pickling cucumbers grown in a high tunnel. Notulae Botanicae Horti Agrobotanici Cluj-Napoca 2016, 44, 541-547.

40. Cataldo, D.; Haroon, M.F.; Schäder, E.; Youngs, V. Rapid colorimetric determination of nitrate in plant tissue by nitrification of salicylic acid. Commun. Soil Sci. Plant Anal. 1975, 6, 71-80. [CrossRef]

41. Arya, S.P.; Mahajan, M.; Jain, P. Non-spectrophotometric methods for the determination of vitamin C. Anal. Chim. Acta 2000, 417, 1-14. [CrossRef]

42. Grandy, A.S.; Erich, M.S.; Porter, G.A. Suitability of the anthrone-sulfuric acid reagent for determining water soluble carbohydrates in soil water extracts. Soil Biol. Biochem. 2000, 32, 725-727. [CrossRef]

43. Sedmak, J.J.; Grossberg, S.E. A rapid, sensitive, and versatile assay for protein using Coomassie brilliant blue G250. Anal. Biochem. 1977, 79, 544-552. [CrossRef]

44. Vlaic, R.A.; Muresan, V.; Muresan, A.E.; Muresan, C.C.; Paucean, A.; Mitre, V.; Chis, S.M.; Muste, S. The Changes of polyphenols, flavonoids, anthocyanins and chlorophyll content in plum peels during growth phases: From Fructification to Ripening. Notulae Botanicae Horti Agrobotanici 2017, 46, 148. [CrossRef]

45. Barbero, G.F.; Liazid, A.; Palma, M.; Barroso, C.G. Fast determination of capsaicinoids from peppers by high-performance liquid chromatography using a reversed phase monolithic column. Food Chem. 2008, 107, 1276-1282. [CrossRef]

46. Reilly, C.A.; Crouch, D.J.; Yost, G.S.; Reilly, C.A.; Crouch, D.J.; Yost, G.S. Quantitative analysis of capsaicinoids in fresh peppers, oleoresin capsicum and pepper spray products. J. Forensic Sci. 2001, 46, 502-509. [CrossRef] [PubMed]

47. Foyer, C.H.; Valadier, M.H.; Migge, A.; Becker, T.W. Drought-induced effects on nitrate reductase activity and mRNA and on the coordination of nitrogen and carbon metabolism in maize leaves. Plant Physiol. 1998, 117, 283-292. [CrossRef]

48. Rockel, P.; Strube, F.; Rockel, A.; Wildt, J.; Kaiser, W.M. Regulation of nitric oxide (NO) production by plant nitrate reductase in vivo and in vitro. J. Exp. Bot. 2002, 53, 103-110. [CrossRef]

49. Rizwan, M.; Mostofa, M.G.; Ahmad, M.Z.; Zhou, Y.; Adeel, M.; Mehmood, S.; Ahmad, M.A.; Javed, R.; Imtiaz, M.; Aziz, O. Hydrogen sulfide enhances rice tolerance to nickel through the prevention of chloroplast damage and the improvement of nitrogen metabolism under excessive nickel. Plant Physiol. Biochem. 2019, 138, 100-111. [CrossRef]

50. Livak, K.J.; Schmittgen, T.D. Analysis of relative gene expression data using real-time quantitative PCR and the 2(-Delta Delta C(T)) method. Methods 2001, 25, 402-408. [CrossRef] 
51. Cao, H.; Ge, Y.; Liu, D.; Cao, Q.; Chang, S.X.; Chang, J.; Song, X.; Lin, X. Nitrate/ammonium ratios affect ryegrass growth and nitrogen accumulation in a hydroponic system. J. Plant Nutr. 2011, 34, $206-216$. [CrossRef]

52. Bloom, A.J.; Meyerhoff, P.A.; Taylor, A.R.; Rost, T.L. Root development and absorption of ammonium and nitrate from the rhizosphere. J. Plant Growth Regul. 2002, 21, 416-431. [CrossRef]

53. Liu, H.; Yang, H.; Zheng, J.; Jia, D.; Wang, J.; Li, Y.; Huang, G. Irrigation scheduling strategies based on soil matric potential on yield and fruit quality of mulched-drip irrigated chili pepper in northwest China. Agric. Water Manag. 2012, 115, 232-241. [CrossRef]

54. Drew, M.C.; Webb, J.; Saker, L.R. Regulation of $\mathrm{K}^{+}$uptake and transport to the xylem in barley roots; $\mathrm{K}^{+}$ distribution determined by electron probe X-ray microanalysis of frozen-hydrated cells. J. Exp. Bot. 1990, 41, 815-825. [CrossRef]

55. Lu, Y.X.; Li, C.J.; Zhang, F.S. Transpiration, potassium uptake and flow in tobacco as affected by nitrogen forms and nutrient levels. Ann. Bot. 2005, 95, 991-998. [CrossRef]

56. Traore, A.; Maranville, J. Effect of nitrate/ammonium ratio on biomass production, nitrogen accumulation, and use efficiency in sorghums of different origin. J. Plant Nutr. 1999, 22, 813-825. [CrossRef]

57. Na, L.; Li, Z.; Meng, X.; Ara, N.; Yang, J.; Zhang, M. Effect of nitrate/ammonium ratios on growth, root morphology and nutrient elements uptake of watermelon (Citrullus Lanatus) seedlings. J. Plant Nutr. 2014, 37, 1859-1872. [CrossRef]

58. Shaviv, A.; Hagin, J. Interaction of ammonium and nitrate nutrition with potassium in wheat. Fertil. Res. 1988, 17, 137-146. [CrossRef]

59. Becker, J.; Silvia Plaza Maria, B.; Teresa, M. Empirical models of potassium uptake by dieffenbachia amoena 'Tropic Snow' under different nitrogen sources. HortScience 2009, 44, 483-486. [CrossRef]

60. Yoneyama, T.; Matsumaru, T.; Usui, K. Engelaar Wmhg: Discrimination of nitrogen isotopes during absorption of ammonium and nitrate at different nitrogen concentrations by rice (Oryza sativa L.) plants. Plant Cell Environ. 2001, 24, 133-139. [CrossRef]

61. Sokri, S.M.; Babalar, M.; Barker, A.V.; Lesani, H.; Asgari, M.A. Fruit quality and nitrogen, potassium, and calcium content of apple as influenced by nitrate: Ammonium ratios in tree nutrition. J. Plant Nutr. 2015, 38, 1619-1627. [CrossRef]

62. Tu, B.; Liu, C.; Tian, B.; Zhang, Q.; Liu, X.; Herbert, S.J. Reduced abscisic acid content is responsible for enhanced sucrose accumulation by potassium nutrition in vegetable soybean seeds. J. Plant Res. 2017, 130, 551-558. [CrossRef] [PubMed]

63. Zhang, W.; Zhang, N.S.; Zhao, J.J.; Guo, Y.P.; Zhao, Z.Y.; Mei, L.X. Potassium fertilization improves apple fruit (Malus domestica Borkh. Cv. Fuji) development by regulating trehalose metabolism. J. Hortic. Sci. Biotechnol. 2017, 92, 1-11. [CrossRef]

64. Xu, G.; Kafkafi, U.; Wolf, S.; Sugimoto, Y. Mother plant nutrition and growing condition affect amino and fatty acid compositions of hybrid sweet pepper seeds. J. Plant Nutr. 2002, 25, 1645-1665. [CrossRef]

65. Gurung, T.; Techawongstien, S.; Suriharn, B.; Techawongstien, S. Stability analysis of yield and capsaicinoids content in chili (Capsicum spp.) grown across six environments. Euphytica 2012, 187, 11-18. [CrossRef]

66. Das, S.; Teja, K.C.; Duary, B.; Agrawal, P.K.; Bhattacharya, S.S. Impact of nutrient management, soil type and location on the accumulation of capsaicin in Capsicum chinense (Jacq.): One of the hottest chili in the world. Sci. Hortic. 2016, 213, 354-366. [CrossRef]

67. Kim, S.; Park, M.; Yeom, S.I.; Kim, Y.M.; Lee, J.M.; Lee, H.A.; Seo, E.; Choi, J.; Cheong, K.; Kim, K.T.; et al. Genome sequence of the hot pepper provides insights into the evolution of pungency in Capsicum species. Nat. Genet. 2014, 46, 270-278. [CrossRef]

68. Mazourek, M.; Pujar, A.; Borovsky, Y.; Paran, I.; Mueller, L.; Jahn, M.M. A dynamic interface for capsaicinoid systems biology. Plant Physiol. 2009, 150, 1806-1821. [CrossRef]

69. Sagi, M.; Dovrat, A.; Kipnis, T.; Lips, H. Nitrate reductase, phosphoenolpyruvate carboxylase, and glutamine synthetase in annual ryegrass as affected by salinity and nitrogen. J. Plant Nutr. 1998, 21, 707-723. [CrossRef]

70. Jampeetong, A.; Brix, H. Nitrogen nutrition of Salvinia natans: Effects of inorganic nitrogen form on growth, morphology, nitrate reductase activity and uptake kinetics of ammonium and nitrate. Aquat. Bot. 2009, 90, 67-73. [CrossRef] 
71. Konnerup, D.; Brix, H. Nitrogen nutrition of Canna indica: Effects of ammonium versus nitrate on growth, biomass allocation, photosynthesis, nitrate reductase activity and $\mathrm{N}$ uptake rates. Aquat. Bot. 2010, 92, 142-148. [CrossRef]

72. Vincentz, M.; Moureaux, T.; Leydecker, M.T.; Vaucheret, H.; Caboche, M. Regulation of nitrate and nitrite reductase expression in Nicotiana plumbaginifolia leaves by nitrogen and carbon metabolites. Plant J. 2010, 3, 315-324. [CrossRef] [PubMed]

73. Cruz, C.; Bio, A.F.M.; Domínguez-Valdivia, M.D.; Aparicio-Tejo, P.M.; Lamsfus, C.; Martins-Loução, M.A. How does glutamine synthetase activity determine plant tolerance to ammonium? Planta 2006, 223, 1068-1080. [CrossRef] [PubMed]

74. Glass, A.D.; Britto, D.T.; Kaiser, B.N.; Kinghorn, J.R.; Kronzucker, H.J.; Kumar, A.; Okamoto, M.; Rawat, S.; Siddiqi, M.Y.; Unkles, S.E. The regulation of nitrate and ammonium transport systems in plants. J. Exp. Bot. 2002, 53, 855-864. [CrossRef] [PubMed]

75. Mihaljević, S.; Radić, S.; Bauer, N.; Garić, R.; Mihaljević, B.; Horvat, G.; Leljak-Levanić, D.; Jelaska, S. Ammonium-related metabolic changes affect somatic embryogenesis in pumpkin (Cucurbita pepo L.). J. Plant Physiol. 2011, 168, 1943-1951. [CrossRef] [PubMed]

76. Li, J.; Zhou, J.; Duan, Z. Effects of elevated $\mathrm{CO}_{2}$ concentration on growth and water usage of tomato seedlings under different ammonium/nitrate ratios. J. Environ. Sci. 2007, 19, 1100-1107. [CrossRef]

77. Shen, H.; Yang, H.; Guo, T. Influence of arbuscular mycorrhizal fungi and ammonium: Nitrate ratios on growth and pungency of spring onion plants. J. Plant Nutr. 2011, 34, 743-752. [CrossRef]

78. Choi, S.T.; Park, D.S.; Hong, K.P. Status of nitrogenous and carbohydrate compounds as affected by nitrogen fertigation rates in young persimmon trees. Sci. Hortic. 2011, 130, 354-356. [CrossRef]

79. Lea, U.S.; Marie-Thérèse, L.; Isabelle, Q.; Christian, M.; Cathrine, L. Posttranslational regulation of nitrate reductase strongly affects the levels of free amino acids and nitrate, whereas transcriptional regulation has only minor influence. Plant Physiol. 2006, 140, 1085-1094. [CrossRef]

80. Zhong, F.; Wang, S.; Lin, J.; Roan, S.F.; Lin, B.; Zhou, X.; Chen, I.Z.; Lin, Y.; Jie, P.; Shuang, W. Characterization of nitrate assimilation in Lactuca sativa L. under different nitrogen sources. Plant Growth Regul. 2018, 86, 1-10. [CrossRef]

(C) 2019 by the authors. Licensee MDPI, Basel, Switzerland. This article is an open access article distributed under the terms and conditions of the Creative Commons Attribution (CC BY) license (http://creativecommons.org/licenses/by/4.0/). 